\title{
Lifetime Health Consequences of Child Labor in Brazil
}

\author{
Chanyoung Lee ${ }^{\mathrm{a}}$ \\ Peter F. Orazem ${ }^{b}$
}

\section{September 2009}

The health consequences of child labor may take time to manifest themselves. This study examines whether children who began working at a young age experience increased incidence of illness or physical disability as adults.. When child labor and schooling are treated as chosen without consideration of unobserved abilities or health endowments, child labor appears to have small adverse effects on a wide variety of health measures. Some adverse health consequences such as heart disease or hypertension seem unlikely to be caused by child labor. However, when we allow unobserved health and ability endowments to alter the age of labor market entry and years of schooling completed, the joint effects of child labor and schooling on health become larger while the less plausible health consequences lose significance. Results imply that delaying entry into child labor while increasing time in school significantly lowers the probability of early onset of physical ailments such as back problems, arthritis, or reduced strength or stamina. However, our methods are not able to distinguish between the health impacts of child labor from the impacts of reduced time in school. .

\footnotetext{
${ }^{a}$ Samsung Economic Research Institute, Korea, chanyoung7.lee@samsung.com

${ }^{\mathrm{b}}$ Department of Economics, Iowa State University, Ames IA 50011-1070, USA, pfo@iastate.edu We received excellent advice on this paper from Mary Arends-Kuenning, Eric Edmonds, Patrick Emerson, Wally Huffman, Brent Kreider, Justin Tobias, referees, and colleagues at the University of Illinois, the IZA/World Bank Development Conference, the Midwest Economic Association, and the University of Minnesota.
} 


\section{Introduction}

The International Labor Organization (ILO) Convention 182 calls for the prohibition and elimination of the worst forms of child labor. In addition to universally condemned occupations such as child slavery, prostitution, pornography and drug trafficking, the worst forms include work that is likely to jeopardize the health, safety or morals of young persons (ILO, 1999). The ILO estimates that there are 111 million children aged 5 to 14 involved in hazardous work. ${ }^{1}$ This number is equivalent to $53 \%$ of working children and about $9 \%$ of all children in the world. Children engaged in such activities are presumed to face immediate health threats by the nature of the work. However, child labor could also have health consequences that only become manifest in adulthood. Such long-term health risks can develop from early exposure to dust; toxins; chemicals such as fertilizer and pesticides; inclement weather; heavy lifting; or the forced adoption of poor posture. Hazards may also threaten psychological health through exposure to abusive relationships with employers, supervisors or clients (ILO, 1998).

The linkage between working as a child and health status later as an adult has not been widely explored. This study aims to fill that knowledge gap by examining whether adults who entered the labor market early in life suffer higher rates of chronic diseases and functional limitations in adulthood. We address the question using the 1998 Pesquisa Nacional por Amostra de Domicilios (PNAD) which included a series of questions on health and disability status. It also included questions on whether current adults worked as children.

\footnotetext{
${ }^{1}$ All children aged 5-14 are considered by the ILO to be engaged in hazardous work if they are working in mining or construction or in occupations or processes considered hazardous by their nature or if they work more than 43 hours per week.
} 
Estimating the causal effect of child labor on adult health is complicated by the selection process which sorts children into the labor market. On the one hand, we might expect that only reasonably healthy children would be sent to work at young ages. Sickly children would not be capable of work. On the other hand, children from the poorest households are the most likely to work, and growing up in poverty may be correlated with adverse health outcomes. ${ }^{2}$ Thus, the early incidence of child labor may be correlated with unobservable positive or negative health endowments that could affect adult health in addition to any direct impact of child labor on health. These unobserved health endowments cloud the interpretation of simple correlations between child labor and adult health outcomes. A second factor that complicates measuring child labor's effect on adult health is that child labor can affect years of schooling completed, and education has been shown to positively affect adult health. ${ }^{3}$ The effect of child labor on education in Brazil is uncertain. Because the average school day lasts only four hours, many children in Brazil both work and attend school. Child labor may help the household afford more years of schooling. On the other hand, child labor may retard child cognitive attainment per year of schooling, and it may also lead to earlier exit from school into full time work. ${ }^{4}$ Any complete assessment of the effect of child labor on health must take into account the indirect effect of child labor on

\footnotetext{
${ }^{2}$ Case et al. (2002) and Currie and Stabile (2003) present evidence that children in poorer families have significantly worse health than children in richer families.

${ }^{3}$ Studies have consistently found a large positive correlation between education and health. For examples, see Van Doorslaer (1987), Wagstaff (1993), Grossman and Kaestner (1997), and Lleras-Muney (2005).

${ }^{4}$ The weight of evidence suggests that child labor is negatively correlated with schooling attainment (Psacharopoplous, 1997; Duryea and Arends-Kuenning, 2003; Rosati and Rossi, 2003; Orazem et al, 2009). Nevertheless, some studies find that child labor and schooling are compatible (Patrinos and Psacharopoulos, 1997; Ravallion and Wodon, 2000). There is stronger evidence that child labor lowers test scores, presumably because it makes time in school less efficient (Post and Pong, 2000; Heady, 2003; Rosati and Rossi , 2003; Gunnarrson et al, 2006).
} 
schooling. From the analysis, we may see whether the effect of child labor on health can be isolated from the effect of allocated time in school on health.

In this study, adult health is measured by the incidence of chronic diseases and by functional limitations in performing activities. We estimate the relationship of these adult health outcomes to child labor first by assuming that age of labor market entry and years of schooling completed are chosen by parents without consideration of child endowments of health or schooling ability. We then use the availability and quality of local schools and the relative wages paid for low skill labor at the time the adult was a child to provide plausible sources of independent variation in the age of labor market entry and years of schooling completed. These variables affected the relative value and cost of child time in school versus work and of household ability to support child time in school and so they should have influenced labor supply and schooling decisions during childhood. However, these factors should have no direct impact on the child's health a quarter century later in adulthood.

When we ignore the selection process that sorts children into work and out of school, child labor is positively correlated with a higher incidence of adult chronic diseases and functional limitations, but the impacts are very small. When we control for that selection process using instrumental variables methods, the effects of child labor and schooling on adult health become larger and more concentrated on physical ailments such as back problems, arthritis, and reduced physical strength and stamina. The combined effect of increasing time in school while delaying labor market yields significant improvements in health when these children become adults. However, our instruments do not provide sufficient independent variation in time spent working versus time spent in school to isolate the impact of delaying entry into the workforce from spending more time in school. 
The next section summarizes the literature on child labor and long-term health. In section III, we describe our model and estimation strategy. Section IV provides data and descriptive statistics. In section V, we present empirical results. In section VI, we summarize our findings and their implications for policy and further research.

\section{Literature Review}

Until recently, most studies linking child labor and health have focused on the health of currently working children. The comprehensive review by Graitcer and Lerer (1998) presented a mixed picture of international evidence regarding the impact of child labor on health, primarily because of data limitations. Data on the extent of child labor itself is subject to considerable error, but data on the incidence of child injuries on the job are even more problematic. Sources of information come from government surveillance, sometimes supplemented by data from worker's compensation or occupational health and safety incidence reports. These latter sources are less likely to be present in the informal labor markets in which child labor is most common, and government surveillance is often weak. Nevertheless, reported injury rates are not small: of working children aged 10-14, 9\% are estimated to suffer injuries annually, and 3.4\% are estimated to suffer disabling injuries.

Two recent studies have examined the impacts of child labor on child health using the Vietnam Living Standards Survey, but their findings are inconsistent. O'Donnell et al (2005) found that unpaid child labor has no apparent adverse impact on current health and that paid child labor may even improve health. However, there is some evidence that child labor can increase incidence of illness up to five years after starting to work. Using a different estimation strategy, Beegle et al (2004) did not find significant adverse health consequences of child labor. 
Information on longer term health consequences of child labor such as occupational diseases or repetitive motion injuries is even more limited. In a rare example of longitudinal data applied to the question, Satyanarayana et al (1986) examined anthropometric data on 410 children over a 17 year period in a rural area in India. They found that children who worked in agriculture, small-scale industry and services gained less in height and weight when followed through to adulthood than those who attended school. They did not control for factors other than child labor that might also lead to adverse health outcomes, nor did they control for possible nonrandom selection into work or industry. Two larger-scale studies using different Brazilian data sets provide some evidence on the negative long term effect of child labor on adult health. Kassouf et al (2001) and Giuffrida et al (2005) found that children who worked at young ages had increased incidence of various self-reported adverse health outcomes as adults. While these studies do not control for the possible endogeneity of child labor, they do control for factors that could also affect adult health such as age, race, education, wealth, housing conditions, and unemployment status. However, some of these controls such as wealth, housing status and unemployment later in life may themselves be consequences of having worked as a child which will bias the estimated effect of child labor on adult health.

Rosati and Straub (2004) used a sample of Guatemalan siblings that controlled for unobservable household attributes in assessing the impact of child labor on adult health. However their strategy still treats child labor and possible resulting decisions regarding schooling and income as exogenous. In addition, their sample is restricted to adults who are still living with their parents, and so their sample is heavily weighted toward relatively young adults. Moreover, if the decision to live with parents is conditioned on health outcomes, as 
would be the case if healthy children are more likely to live on their own and children suffering illness or disability are more likely to remain with their parents, then their sample will be biased toward finding adults with health problems. Selection might explain why they find such large adverse health consequences: having worked as a child increased by $40 \%$ the probability of having health problems as an adult. Nevertheless, their finding of very large health consequences from child labor illustrates the importance of further examining the link between child labor and adult health.

Brazilian data does appear to support a prima facie case that starting to work early in life can lead to the early onset of physical disabilities in adulthood. Figure 1 shows the relationship between age of labor market entry and various health conditions for several birth cohorts in Brazil. Adults who started working earliest as children have a higher incidence of back problems and arthritis than do their contemporaries who entered the labor market at older ages. Older cohorts have a higher incidence of these problems than younger cohorts, but the downward pattern between health problems and age of labor market entry is found in all cohorts. Interestingly, there is no apparent pattern between the incidence of hypertension and age of labor market entry. Presumably, the incidence of hypertension would be tied more closely to heredity and life style and less to early labor market entry.

\section{"Insert Figure 1"}

Similar downward patterns between age of labor market entry and the self-reported incidence of other physical ailments are found for walking, bending, lifting, pushing, and climbing stairs, a subset of which are shown in Appendix 1. The only physical ailment without this negative correlation is tendonitis. In contrast, no apparent correlation between child labor and adult health exists for self-reported asthma, diabetes, cancer, tuberculosis, 
cirrhosis, depression, and heart disease, health conditions that should reflect heredity and life style choices rather than physical stress. Of these illnesses, only kidney disease has an apparent negative correlation with age of labor market entry. The pattern of these correlations suggests that there may indeed be a relationship between starting to work at a young age and poor lifetime health. The balance of the paper examines whether we can identify a causal link between child labor and adult health that is consistent with these correlations.

\section{Model and Estimation Strategy}

\section{A. Conceptual model: A household model of child labor and schooling and adult health}

We need a model that relates a possible causal link between working early in life and health outcomes later in life. However, numerous studies have shown that child labor and time in school are jointly determined. Because schooling itself can affect health, the model must also allow for this alternative avenue by which child time allocations can affect health later in life.

Suppose that households have a single parent and a single child. The parent works full time, earning income $Y$. The child's time normalized to unity is divided between leisure ( $\left.L^{1}\right)$; child labor $\left(C^{1}\right)$; and schooling $\left(S^{1}\right)$; so $1=L^{1}+C^{1}+S^{1}$. The superscript refers to the childhood period. If the child works, she is paid an exogenous wage, $W^{1}$. If she attends school, she accesses exogenous school inputs, $Z^{1}$.

The parent gets utility from the child's future wealth, $\left(U_{W^{2}}>0\right)$ where future wealth has the form $W^{2}=W^{2}\left(C^{1}, S^{1}, Z^{1}, a, h, H^{2}\right)$. Wealth depends on how much time the child spends on school and work in the first period; on the child's fixed endowments of ability $(a)$ and 
health $(h)$; and on the future health of the child, $H^{2}=H^{2}\left(C^{1}, S^{1}, a, h\right)$. The child's future health also depends on how the child's time is allocated between school and work and on the ability and health endowments. Parents also derive utility from child leisure $\left(U_{L^{1}}>0\right)$ and from consumption of goods, $X$, $\left(U_{X}>0\right)$.

The parents choose current consumption, child labor, and child time in school so as to maximize utility $U\left[X,\left(1-C^{1}-S^{1}\right), W^{2}\left(C^{1}, S^{1}, Z^{1}, a, h, H^{2}\right)\right]$ subject to the budget constraint $Y+W^{1} C^{1}=P X$ where $P$ is the price of consumer goods purchased by the parent. Assuming interior solutions, the first order conditions imply that

$$
\frac{U_{X}}{P} W^{1}+U_{W^{2}}\left(\frac{\partial W^{2}}{\partial C^{1}}+\frac{\partial W^{2}}{\partial H^{2}} \frac{\partial H^{2}}{\partial C^{1}}\right)=U_{W^{2}}\left(\frac{\partial W^{2}}{\partial S^{1}}+\frac{\partial W^{2}}{\partial H^{2}} \frac{\partial H^{2}}{\partial S^{1}}\right)
$$

The left-hand-side of the equality is the marginal utility the parents derive from child labor. Child labor increases household income which increases parental consumption, but child labor also affects the future wealth of the child. Parents will discount the utility they get from consumption derived from child labor if at the same time they compromise the child's lifetime wealth, either because child labor directly reduces future earning as an adult $\left(\frac{\partial W^{2}}{\partial C^{1}}<0\right)$; or because child labor reduces earnings through an adverse impact on lifetime health $\left(\frac{\partial H^{2}}{\partial C^{1}}<0\right)$. The right-hand-side of the equality (1) is the marginal utility from allocating child time to school. Schooling can affect the child's future wealth directly through its impact on skill development or indirectly through its impact on lifetime health.

The reduced form equations for child time allocation to work and school will depend on all the exogenous variables $W^{1}, Z^{1}, a, h, Y$, and $P$. These reduced form equations will 
prove useful in identifying child labor and time in school as we explore their impacts on adult health outcomes implied by the health production equation $H^{2}=H^{2}\left(C^{1}, S^{1}, a, h\right)$.

\section{B. Estimation strategy}

We use our stylized household model to identify the variables entering the reduced form child labor and schooling equations. The linear approximations to these equations for a child $i$ born in state $j$ as a member of age cohort $t$ are of the form

$$
\begin{aligned}
& C_{i j t}^{1}=\varphi_{Z}^{C} Z_{j t}^{1}+\varphi_{W}^{C} W_{j t}^{1}+\varphi_{Y}^{C} Y_{j t}+D_{i j t}^{\prime} \varphi_{D}^{C}+\delta_{j}^{C}+\delta_{t}^{C}+\varepsilon_{i j t}^{C} \\
& S_{i j t}^{1}=\varphi_{Z}^{S} Z_{j t}^{1}+\varphi_{W}^{S} W_{j t}^{1}+\varphi_{Y}^{S} Y_{j t}+D_{i j t}^{\prime} \varphi_{D}^{S}+\delta_{j}^{S}+\delta_{t}^{S}+\varepsilon_{i j t}^{S}
\end{aligned}
$$

The variables $Z^{l}, W^{l}$, and $Y$ are included as required by the reduced form. The vector $D_{i j t}$ is composed of exogenous demographic attributes that only include time invariant race or gender or clearly exogenous age. We do not include other adult outcomes such as occupation, employment status, marital status, the presence of children, or other choices that would be conceivably correlated with health or ability endowments. To the extent that these variables are choices conditioned on schooling or child labor choices earlier in life, they would be endogenous to adult health outcomes and must therefore be excluded from the empirical model. The dummy variables $\delta_{j}^{k}$ and $\delta_{t}^{k}$ control for differences in prices across cohorts and across birth states, but they will also help to control for differences in the mix of jobs children undertake across birth states and across time.

The error terms contain unobserved ability and health endowments which theory suggests ought to enter the reduced from equations, so that

$$
\varepsilon_{i j t}^{k}=\alpha_{a}^{k} a_{i j t}+\alpha_{h}^{k} h_{i j t}+\xi_{i j t}^{k} ; k=C, S .
$$

The last term $\xi_{i j t}^{k}$ is an iid random error. The reduced form equations (2) and (3) demonstrate that parental choices on age of labor market entry and child time in school will depend on parental observations of the child's endowments of ability and health. If, for example, the parameters in (4), $\alpha_{a}^{k}$ and $\alpha_{h}^{k}$ are positive, then children born with better health and ability will both work more and attend school more in period 1. 
In period 2, these endowments of health and ability will carry over to observations of adult health. Let the equation explaining adult health be given by

$$
H_{i j t}^{2}=D_{i j t}^{\prime} \beta_{D}+\beta_{C} C_{i j t}^{1}+\beta_{S} S_{i j t}^{1}+\delta_{j}^{H}+\delta_{t}^{H}+\varepsilon_{i j t}^{H}
$$

whereas before, the error term has the form $\varepsilon_{i j t}^{H}=\alpha_{a}^{H} a_{i j t}+\alpha_{h}^{H} h_{i j t}+\xi_{i j t}^{H}$. Because adult health is conditioned on unobserved health and ability endowments, $\operatorname{COV}\left(\varepsilon_{i j t}^{H}, C_{i j t}^{1}\right) \neq 0$ and $\operatorname{COV}\left(\varepsilon_{i j t}^{H}, S_{i j t}^{1}\right) \neq 0$. Ordinary least squares applied to equation (5) will yield biased estimates of $\beta_{C}$ and $\beta_{S}$. To continue our hypothetical example, if the parameters $\alpha_{a}^{H}$ and $\alpha_{h}^{H}$ are also positive, $\beta_{C}$ and $\beta_{S}$ will overstate the impact of child labor and years of schooling on observed health. If the true value of $\beta_{C}<0$, then the coefficient on child labor will be biased against finding an adverse effect of child labor on adult health.

Our point is not to predict the direction of bias, but simply to indicate that unobserved health and ability endowments in childhood will cloud our interpretation of the consequences of decisions made in childhood on adult health. However, if our assumption that adult health is not directly influenced by the period 1 school attributes $Z_{j t}^{1}$, child wages $W^{1}$, or household incomes $Y$, then we have a battery of instruments with which to identify the true effect of child labor and years of schooling on adult health. Inserting the expected values of $C_{i j t}^{1}$ and $S_{i j t}^{1}$ into (5), we obtain

$$
\begin{gathered}
H_{i j t}^{2}=D_{i j t}^{\prime} \beta_{D}+\beta_{C}\left(\varphi_{Z}^{C} Z_{j t}^{1}+\varphi_{W}^{C} W_{j t}^{1}+\varphi_{Y}^{C} Y_{j t}+D_{i j t}^{\prime} \varphi_{D}^{C}+\delta_{j}^{C}+\delta_{t}^{C}\right)+\beta_{S}\left(\varphi_{Z}^{S} Z_{j t}^{1}+\varphi_{W}^{S} W_{j t}^{1}+\right. \\
\left.\varphi_{Y}^{S} Y_{j t}+D_{i j t}^{\prime} \varphi_{D}^{S}+\delta_{j}^{S}+\delta_{t}^{S}\right)+v_{i j t}^{H}
\end{gathered}
$$

The hypothesized exclusion restrictions generate variation in child labor and years of schooling that is uncorrelated with the unobserved ability and health endowments, and so we can derive unbiased estimates of $\beta_{C}$ and $\beta_{S}$. Our strategy is to estimate equations (2), (3), and (6) jointly in order to derive efficient estimates of the coefficients of interest. ${ }^{5}$ Because equations (2) and (3) have interest in and of themselves, insomuch as they show how the

\footnotetext{
${ }^{5}$ Emerson and Souza (2006) employ a similar approach to identify causal relationships between child labor and adult earnings.
} 
economic and school environment affects decisions on years of schooling and child labor, we report those estimates as well. Finally, to provide a frame of reference for the estimates in (6), we estimate (5) directly to illustrate the nature of the biases.

\section{Instruments}

We observe health outcomes in period 2 when the individual is an adult, but decisions on child labor and schooling occur in period 1 when the individual is a child. Both child labor and years of schooling are period 1's household decisions that reflect unobservable characteristics of the individual's family. To properly control for the potential endogeneity of child work activity and years of education in the adult health production function, we need instruments that would affect age of entry into the labor market and years of schooling completed but would not directly affect health during adulthood. We do not have information on family background measures for adults during period 1 when they were children, and so we need to look to other sources of information for factors that should affect these schooling and labor market choices.

The vector $Z^{l}$ would include the availability and quality of schools in the area where the adult grew up. ${ }^{6}$ The presence of more schools per child residing in the state lowers the average travel costs of attending schooling in the state. Similarly the number of teachers per child can be used as a proxy for school quality in the state. Since age 7 is the age of school entry in Brazil, we use the number of schools per child and the number of teachers per child at age 7 in the state in which the individual was born as our measures of period 1 school availability and school quality.

\footnotetext{
${ }^{6}$ Bedi and Edwards (2002), Gertler and Glewwe (1990), Duflo (2001, 2004), Glick and Sahn (2006), and Alderman et al (2001) all found evidence that schooling decisions are influenced by distance and/or school quality.
} 
We do not have household information on $W^{l}$ and $Y$ but we do observe local unskilled wages that should be correlated with the opportunity cost of schooling. Because relatively few children work for wages, information on average pay for children is extremely limited and subject to selection problems. ${ }^{7}$ Instead, we use the relative wage for workers in the state with four or fewer years of schooling as an indicator of the value of time for illiterate labor in period $1 .{ }^{8}$ Because average schooling levels for parents at the time would have been around four years, rising low-skill wages will increase the income potential of the parents as well as the children. Therefore, we use this measure as a general indication of the relative strength of labor demand in the state and do not try to differentiate between child and parent wage levels. We date our low skill wage to the time the adult was 12 years old in the state of birth, the youngest age at which a child could legally work in Brazil.

We do not have information on local prices, but our dummy variables for state of birth and age cohort will help control for price variation across states and across time. These dummy variables are not treated as instruments, and so we also include them in the secondstage health regressions.

As we will demonstrate below, these instruments have strong predictive power for both the age of labor market entry and for years of schooling completed. In addition, they have signs that are consistent with the presumed roles of these variables in shaping the attractiveness of schools, and the opportunity cost of child time on the endogenous variables. However, they do not have direct predictive power for adult health, and so they meet the empirical criteria for valid instruments.

\footnotetext{
${ }^{7}$ Card (1995) and Cameron and Taber (2004) used local labor market conditions as opportunity cost of schooling. Rosenzweig (1980) used agricultural day wages in India.

${ }^{8}$ It is commonly presumed that it takes about five years of schooling to attain permanent literacy.
} 
An important side benefit to the instrumental variables strategy is that it also serves as a correction for possible measurement error in our measures of schooling and child labor. Age of labor market entry will be particularly subject to recall errors, but even years of schooling has been shown to have measurement errors (Ashenfelter and Krueger, 1994). Independent of the other sources of bias, measurement errors in the age of labor market entry will tend to bias our estimated effects of child labor on health toward zero. A classic correction would be to use the instrumented measures of child labor and of years of schooling in place of their reported values. The biggest weakness in our strategy is the lack of information on the socioeconomic status or wealth of the parents, $Y$. Parental wealth is plausibly correlated with the adult health of their children and is also plausibly correlated with the availability and quality of local schools and with local wages. Even if our instruments are legitimate, missing information on $Y$ may create a correlation between those instruments and adult health outcomes. In particular, states with high average wealth may produce children who have better health outcomes as an adult. Our inclusion of state and cohort dummy variables mitigate this concern somewhat in that they will capture some of that correlation between state average wealth and health, but we cannot prove that our results are purged of bias attributable to missing $Y$.

\section{Data and Descriptive Analysis}

\section{A. Data}

The main source of data used for the analyses is 1998 Pesquisa Nacional Por Amostra de Domicilios (PNAD), the Brazilian equivalent of the Current Population Survey in the United States. The PNAD98 collected information from 112,434 households and 344,975 individuals and included information on labor force participation and earnings in conjunction 
with standard demographic characteristics such as age, gender, race, schooling, state of birth and state of residence. Periodically the PNAD survey contains extra questions on such topics as marriage, health, migration, nutrition and social mobility.

The 1998 edition of the PNAD uniquely fits our needs. It included information on the age the respondent first entered the labor market. It also included a special health module which included questions eliciting the respondent's self reported health status. Questions related to twelve specifics chronic diseases or conditions (back problems, arthritis, cancer, diabetes, asthma, hypertension, heart disease, kidney disease, depression, tuberculosis, tendonitis, and cirrhosis) and to seven physical disabilities (difficulty feeding and bathing, raising objects, going upstairs, bending down, carrying and pushing, walking 1 kilometer, and walking 100 meters). Summary information on these and all other variables used in the analysis are presented in Table 1.

A legitimate concern is that self-reported health outcomes will be subject to measurement error. The use of multiple health measures should help allay that concern. We test the robustness of our conclusions by checking for consistent results across multiple measures of health. In addition, any relationship between adult health and child labor should be strongest for physical health measures such as back problems that could plausibly result from early labor market entry as opposed to ailments contracted from bad luck or poor habits (heart and kidney disease). The remaining sources of data are related to construction of the instruments described in the previous section. Data on the number of primary schools, the number of teachers, and the population by state and year are taken from the IBGE Historical 
Series 2003. ${ }^{9}$ We use the number of schools per 1000 children in the state of birth as our measure of school access. School quality is measured by the number of teachers per 1000 children in the state of birth. These measures are dated at the time the respondent was age 7 .

Opportunity cost of adult and child time is measured by the average low skilled wage rate for each census year and state was computed from data in the Integrated Public Use Microdata Series (IPUMS) International. We choose the average pay for workers with four or fewer years of schooling in the year the individual was 12 years old. The IPUMS data only provides wage data every ten years. We interpolate state-specific average wage rates for low-skilled worker between census years using annual measures of per capita income available for each state. We assume that proportional changes in wages are largest in years with the largest increase in average income. The state-level average income measures are compiled from the IPEA historical series. ${ }^{10}$

The sample was selected to include only household heads or their spouses aged 30-55. We exclude older people because we wish to concentrate on the early onset of health complications. As individuals age, all health complications become more common, and so the potential impact of early labor market entry becomes more difficult to isolate. In addition, required information on the wages for low-skilled workers was unavailable for the older birth cohorts. We exclude workers younger than 30 to make sure that all respondents have completed their schooling. ${ }^{11}$

\footnotetext{
${ }^{9}$ We are grateful to Patrick Emerson and Andre Souza for providing us the historical data on schools and teachers by state.

${ }^{10}$ IPEA is the research institute of the Ministry of Planning of the Brazilian Federal Government. These series can be obtained on line at http://www.ipeadata.gov/ipeaweb.dll/ipeadata?1026025750.

${ }^{11}$ Our conclusions were not sensitive to modest changes in the age range. As shown in Figure 1 and in the Appendix, as age rises, health problems become more prevalent because of the aging process and become less sensitive to age of labor market entry.
} 
We further restrict the sample to those who first entered the labor market at or before age 30. This does not greatly affect the sample of males but it does exclude women who never worked and/or were more likely not to respond to the question regarding age of labor market entry. As a result, our sample after deletion of cases with missing data on the variables used includes fewer women $(28,043)$ than men $(39,884)$. For this reason, we also estimated the model separately over the subsamples of men and women to accommodate differences in labor market attachment. This also allows for differential health outcomes across genders that may be related to fertility or to possible occupational differences between men and women.

\section{B. Descriptive analysis}

Table 1 reports the summary statistics for the variables used in the study. Average age of labor market entry is 13.3 years. Male adults entered the labor market 1.4 year earlier. The average years of schooling is 6.8 years with women receiving 0.5 years more schooling than men. The working sample is 60 percent male, 54 percent White, 39 percent Mixed race, and 6 percent Black.

The self-reported adverse health status refers to current health of the individual as an adult. Adverse health incidence ranged from almost 30 percent for back problems to less than 1 percent for cancer, tuberculosis, cirrhosis and inability to walk 100 meters. Other than kidney disease, responses differed significantly between men and women. In most cases, women have higher rates of chronic ailments. There are also seven questions related to the individual's ability to accomplish tasks. ${ }^{12}$ The highest incidence of physical limitation was

\footnotetext{
${ }^{12}$ For chronic conditions, responses were absence or presence of the condition. For disabilities, respondents evaluated their degree of disability as "unable to perform tasks"; "great difficulty performing tasks"; "little
} 
the $9 \%$ reporting difficulty lifting heavy things. Women also report having more task-related disabilities. Although we performed the analysis for all health measures, we focus our discussion on only the most common adverse health outcomes. Results for the most rarely occurring adverse health outcomes were inconclusive.

\section{"Insert Table 1"}

In our sample, there are 25 states and 26 birth years between 1943 and $1968 .^{13}$ Thus, the maximum possible number of different values for each instrument is 650 . To illustrate the range of values, we selected Piaui and Sao Paulo, the poorest and the richest states in Brazil. We also report statistics for Santa Catrina whose gross output per capita is the closest to the country average.

Figure 2a shows the time paths for the number of schools per 1000 children for the three states and for Brazil as a whole. Overall, the average number of schools per 1000 children increased from 4 to 6.5 over 25 years. The availability of schools per child rose the most in the poorest states such as Piaui. Gains in the wealthier states are negligible. More general improvement in quality is apparent in the time paths of teachers per student (Figure 2b). Wealthier states had more teachers per student throughout the period. Figure $2 \mathrm{c}$ shows that the average low-skilled wage remained relatively stable from the mid 1950s to the late 1960s. However, during the 'Brazilian economic miracle' years of the 1970s when real GDP per capita almost doubled, the wages for the least skilled rose everywhere. The gains were

\footnotetext{
difficulty performing tasks"; or "no difficulty performing tasks". We treat the first two responses as indicating disability.

${ }^{13}$ Brazil has 27 states currently. Following the classification in Appendix E of Emerson and Souza (2006), we collapsed the states of Goias and Tocantines, and the states of Mato Grosso and Mato Grosso do Sul. Tocantins and Mato Grosso do Sul were created recently from a division of the old Goias and old Mato Grosso, respectively. Some territories were transformed into states and some states were merged along the $20^{\text {th }}$ century. See Appendix E of Emerson and Souza (2006) for detail information.
} 
greatest in the richest states such as Sao Paulo and more modest in the poorest such as Piaui.

Overall, these charts demonstrate sizeable variation in school availability and quality and in the price of labor across states at a point in time and across cohorts within states.

"Insert Figure 2a-2c"

Figures 3 and 4 show the distributions of the age individuals first entered the labor market, and of their educational attainment. The most common age of labor market entry is 10 , but there is substantial variation across individuals. About one-third of children enter the labor market before the legal working age. A larger percentage of boys than girls started working under age 15 . The years of schooling attained are similarly broadly dispersed.

\section{"Insert Figure 3-4"}

Figure 5 shows that the birth cohort average age of labor market entry increased by only 1.7 years from 11.8 years for those born in 1943 to 13.5 years for those born in 1968 . Over the same period, years of schooling increased 2.8 years from 4 years to 6.8 years.

\section{"Insert Figure 5"}

We saw in Figure 1 that physical ailments occurred with greater frequency for those who began working earlier in life. As shown in Table 1, the incidence of health problems appears greater for women than men even though women were less likely than men to have worked as children. Nevertheless, the correlation with child labor holds up even when we examine the data separately by gender. For example, of women aged 30 to 34, approximately 36 percent of those who started working before age 10 reported back pain as adults. For those who began working after age 14 , only $20 \%$ reported back problems. The incidence of back pain increases with cohort age. The pattern is similar for males, except that a smaller fraction of males report back problems at every age of labor market entry. 
Overall, the descriptive analysis suggests that for both men and women, starting to work at an early age is correlated with earlier onset of some but not all adverse health problems in adulthood. The health problems most correlated with early labor market entry are physical ailments. In the next section, we examine if this pattern remains after controlling for other factors and for nonrandom sorting into school and work.

\section{Empirical Results}

\section{A. Child labor and morbidity treating child labor and education as exogenous}

Table 2 reports the marginal effects of a probit specification of equation (5) for a subset of the more commonly observed adverse health outcomes, holding fixed demographic factors such as age cohort, gender, race, and state of birth. These specifications assume that child labor and years of schooling are exogenous. The results are very consistent regardless of health outcome. Early onset of child labor increases the probability of reporting every adverse health outcome. Increasing years of schooling moderates these effects. For example, an adult who started to work one year earlier is $0.7 \%$ more likely to report back problems holding other factors fixed. The incidence of spinal disorders decreases by about $1 \%$ for each additional year of schooling, controlling for child labor. The other coefficients show that incidence of self-reported spinal disorders increase with age and are larger for women than men.

Similar results are obtained for the impact of child labor on the other health outcomes. Delaying labor market entry by one year lowers the probability of having arthritis as an adult by $0.4 \%$; reduces hypertension by $0.2 \%$; reduces difficulty in raising objects by $0.3 \%$; and lowers difficulty in climbing stairs or walking by $0.1 \%$. Larger positive effects on adult 
health are found from completing an additional year of schooling, ranging from reduced adverse effects as large as $0.7 \%$ for arthritis to $0.2 \%$ for difficulty walking or climbing stairs.

At the bottom of Table 2, we present tests of the joint effect of child labor and schooling. The first test represents the estimated impact of both delaying labor market entry by one year and completing one more year of school on the probability of adverse health impacts. The joint effects are always statistically significant but are small: less than a two percentage point reduction in adverse health incidence. The other test is of the joint null hypothesis that child labor and schooling have no impact on adult health. Again, the results strongly reject the null hypothesis of no effect.

\section{"Insert Table 2"}

Table 3 presents the related estimation for other chronic diseases and physical disabilities. In all cases, child labor is associated with increased probability of adverse health outcomes at a relatively early age in adulthood, although the effects are small. Increasing years of schooling also lowers the likelihood of adverse health outcomes, although again the estimated effects are small. Joint tests of the effects of child labor and schooling are always significant but of modest size.

\section{"Insert Table 3"}

Our results indicate that when child labor is treated as exogenous, child labor is associated consistently with adverse health consequences. The largest adverse impacts are found for physical ailments such as back problems, arthritis, or difficulty raising objects. However, child labor also appears to be related to increased incidence of other health problems that would be less obviously tied to child labor such as hypertension or kidney 
disease. Increasing years of schooling reverses these effects. Of course, these correlations may be due to unobserved ability or health endowments and not to a true causal relationship.

Because the specification in Tables 2 and 3 hold constant the age cohort, an alternative interpretation of the impact of age of entry on adult health is as a measure of exposure to work. For two 40 year old adults, the one who started working at age 10 has four more years of work experience than does the one who started working at age 14. It is plausible that any health effects are due to longer work life and not to working while young per se. Because we only observe health at age 40 rather than repeated health observations at ages between 10 and 40, we do not know when any health problems arose. Only with the latter data could we distinguish between the exposure and child labor interpretations of our results.

\section{B. First-stage estimates of factors affecting child labor and years of schooling}

Our child labor supply and schooling equations (2 and 3) are used to identify child labor and schooling in equation (6). We first demonstrate that our instruments can significantly explain variation in the age at which children first start working and the years of schooling completed. We regress age of labor market entry and years of schooling completed on state-level number of schools per thousand children, number of teachers per thousand children, and the wage for less-educated workers that prevailed at the time the adult was a child.

There is a possibility that individuals live in a state different from their birth state when instruments are applied; at their age 7 or 12. Fiess and Verner (2003) showed that less than $1 \%$ of Brazilian migrated to other states before age 10 , a result that was based on data from the 1990s. It is unlikely that migration rates have fallen over time, and so the $1 \%$ figure 
should be an upper bound measure of migration rates for children between 1950 and 1980. Thus, using information from the state of birth as our measures of the relevant wages and school attributes should not create too many errors.

The regression also includes the individual's time invariant demographic attributes. The inclusion of dummy variable controls for six or seven-year birth cohort and for state of birth mean that our identification depends on differential growth rates of wages and school attributes across states and also on variation in these variables over a six or seven year time interval within states.

Table 4 presents the first-stage regression results. Compared to older cohorts, more recent birth groups have started working later and have spent more time in school. Males start working 1.4 years earlier and receive one-half year less schooling than women. The black and mixed race minorities also start working at earlier ages and receive less schooling.

Better access to schools and better school quality delay labor market entry. Individuals born in states at a time when there are more schools and more teachers per child enter the labor market at older ages. They also spend more time in school, with the marginal effects on time in school and age of labor market entry being nearly identical. Children born in states at a time when there are high wages for workers with less than five years of schooling enter the labor market later in life. The impact of higher low-skill wages on years of schooling is also positive but not statistically significant. We do not have separate information on wages for children and adults, and so we can presume that rising low-skill wages increase labor market earnings for both parents and children. In other settings, general increases in labor demand have been shown to raise family income sufficiently that child labor is no longer needed, as was found by Edmonds and Pavcnik $(2005,2006)$ in Vietnam. 
The null hypothesis that the coefficients on these three variables are jointly equal to zero was easily rejected for both dependent variables, even when we correct our statistical tests for clustering by state of birth.

\section{"Insert Table 4"}

\section{Child labor and morbidity considering child labor and education as endogenous}

Table 5 presents the results of estimating equation (6) jointly with equations (2) and (3). The estimated effects of early entry into labor force and years of schooling on the incidence of selected chronic ailments are shown in the first two rows in each column. Our primary interest is in comparing the IV probit estimate of child labor effects on adult health with those in Tables 2 and 3. Whether because of measurement error or because of the endogeneity of child labor and schooling, the OLS estimates are centered on zero. We illustrate this using box plots for various health measures in Figure 6. The OLS estimates are close to zero. For five of six measures, the IV estimate lies well below the OLS estimate, and for three health measures, the $95 \%$ confidence interval for the IV estimate lies below the OLS measure. The pattern holds for all the other ailments except asthma and tendonitis.

\section{"Insert Table 5"}

Although the IV probit estimates of the impacts of both child labor and schooling on adult health become larger, they also lose significance. None of the individual coefficients is estimated precisely. However, the joint tests still indicate a significant impact of child labor and schooling on adult health. The combined effects of delaying labor market entry by one year while adding one more year of schooling lowers the probability of back problems by $15.7 \%$; lowers incidence of arthritis by $10.9 \%$; and lowers difficulty raising objects by $8.9 \%$. Including the results reported in Table 6 , the other health problems that are significantly 
reduced by delaying labor market entry while increasing schooling are for difficulty climbing stairs, walking, bending over and for kidney disease. Only the last of these is not a physical ailment. We reject the exclusion test for heart problems, but the estimated joint effect of child labor and schooling on heart conditions is not significant. We cannot reject the null hypothesis of no joint effect for hypertension, asthma, depression and tendonitis. The overall pattern of results seems plausible — the largest and most significant joint impacts of child labor and schooling on adult health are found for physical ailments. Smaller and less significant impacts are found for the nonphysical ailments.

\section{"Insert Figure 6"}

It may seem surprising that the joint effects are so significant when the individual effects fail standard tests of significance. However, the individual imprecision of the IV estimates demonstrates that our identification strategy cannot successfully decompose the individual contribution of child labor versus schooling on health, even as it identifies their joint effect. While our predicted measures of age of labor market entry and years of schooling are only correlated at 0.69 , our ability to distinguish between them rests on one overidentifying restriction which is apparently insufficient to isolate the independent effects of these two interrelated decisions. In fact, if we only use age of labor market entry as a regressor and exclude years of schooling, the estimated impacts of child labor on adult health are virtually identical to the joint effects reported in Tables 5 and 6 in both magnitude and significance. Similarly, if we only include years of schooling and exclude age of labor market entry, the estimated impacts of schooling on adult health are again virtually identical to the joint effects in both magnitude and significance. Our IV strategy was able to generate 
precise estimates of the summed effects of child labor and schooling on adult health, but we cannot decompose this joint effect into its child labor and schooling components.

\section{Extensions ${ }^{14}$}

As we saw in Table 1, women are more likely to suffer these ailments than men. Comparing the estimated effect of the Male dummy on health outcomes between Tables 2 and 5, correcting for the choice of schooling and child labor results in a much larger estimated health disadvantage for women. Consequently, it is useful to separate the estimated effects by gender. It is possible that the large differences between men and women reflect differences in labor supply and occupational choices between the sexes, but may also reflect differences in exposure to health problems at an early age.

We replicated the IV probit estimation separately for men and women for all the ailments. Results were quite similar to those reported in Tables 5 and 6 . The estimated effects were larger and more significant for women than for men, but there were no other notable differences. Women have a higher probability of self-reported adverse health outcomes even after controlling for differences across genders in child labor and schooling.

We also explored whether the path from child labor to heightened incidence of physical problems early in life was through occupational choice. If child labor or early exit from schooling led to more physically demanding jobs, then we should find that the link between child labor and health disappears within occupations. That does not happen. Adults working in manufacturing who entered the labor market at younger ages reported more health problems than did their coworkers in manufacturing who entered the labor market at older ages. Similarly, adults with a grade school education who started working at younger

\footnotetext{
${ }^{14}$ Results related to this section are available from the authors on request.
} 
ages reported more physical ailments than did equally educated workers who started working at older ages. In short, if child labor sorts children into an occupational or educational path that leads to increased adverse health outcomes, we could not find that sorting mechanism. The joint effect of child labor and schooling on health appears within occupational or educational groups as well as between those groups.

\section{Conclusion}

This study examines the consequences of child labor on the individual's self-reported health as an adult. It utilizes a unique Brazilian labor market survey that incorporates both contemporaneous measures of health status with retrospective data on child labor. The health measures include both morbidity and work-limiting disabilities. This study takes into account the endogeneity of child labor and years of schooling completed using instrumental variables that measure the direct cost and opportunity cost of schooling and the ability to pay for schooling implicitly at the time the individual was a child and in the state in which the individual was born.

Without correcting for nonrandom selection into child labor or schooling, the results show that earlier labor market entrants suffer consistently from higher incidence of chronic diseases and disabilities. However, the measured adverse consequences are quite small. Furthermore, the estimated effects suggest that child labor causes both physical ailments that are plausibly a consequence of child labor and other health problems that are less clearly tied to working at a young age.

We use instrumental variables to correct for possible endogeneity and measurement error in our measures of child labor and schooling. We find that children who are exposed to better school quality (more teachers relative to the population of children) and more school 
availability when young stay in school longer and delay entry into the labor force. Higher unskilled wages also keep children out of the workforce and in school longer, presumably because their parents can better afford to keep their children in school.

The instrumental variables estimates show that delaying entry into the labor force and increasing time in school combine to significantly lower the incidence of physical ailments such as back problems or arthritis, the health problems one might expect to be associated with physical work. There is only weak evidence of a joint impact of child labor and schooling on health conditions less obviously related to work such as heart and kidney disease or depression.

We were unable to decompose the joint effect into separate effects of child labor and schooling: our instruments were too crude to create sharp distinctions between these two intimately tied choices. Our results suggest that future research might be able to decompose the child labor and school effects on health, but only if instruments can be found that uniquely affect time in school versus time at work.

Nevertheless, our cruder results do have an important policy implication: that improving school quality and availability and faster wage growth for even the least skilled will cause parents to keep their children in school longer. In doing so, children will not only have higher earnings as adults, but they will enjoy improved adult health outcomes as well.

Our findings suffer from one major flaw: our inability to control for parental wealth or socioeconomic status. While our instruments pass standard validity tests, it is still possible that correlation between average unmeasured wealth and observed health outcomes are clouding our results. Findings from this study would justify a more directed survey that tied adult health outcomes more closely to the socioeconomic status of their parents as well as to 
the provision of school services. It would also be useful to collect more detailed retrospective data on occupation and educational choices in order to identify the paths from child labor to adult health. Only with a data set that measures health longitudinally at different ages of the life cycle can we determine if the apparent health consequences from early labor market entry are due to working while young per se as opposed to being exposed to more years of labor. 


\section{References}

Alderman, Harold, Peter F. Orazem and Elizabeth M. Paterno. 2001. "School Quality, School Cost, and the Public/Private School Choices of Low-Income Households in Pakistan." Journal of Human Resources 36 (Spring): 304-326

Ashenfelter, Orley and Alan Krueger. 1994. "Estimates of the Economic Return to Schooling from a New Sample of Twins." The American Economic Review 84 (December): 1157-1173.

Bedi, Arjun S. and John.H.Y.Edwards. 2002. "The Impact of School Quality on Earnings and Educational Returns- Evidence from a Low-Income Country." Journal of Development Economics 68 (June): 157-185.

Beegle, Kathleen, Rajeev Dehejia, and Roberta Gatti. 2004. "Why Should We Care About Child Labor?: The Education, Labor Market and Health Consequences of Child Labor." Journal of Human Resources. Forthcoming.

Cameron, Stephen V. and Christopher R. Taber. 2004. "Estimation of Educational Borrowing Constraints Using Returns to Schooling." Journal of Political Economy 112 (February): 132182.

Card, David. 1995. "Using Geographic Variation in College Proximity to Estimate the Return to Schooling." Aspects of Labour Market Behavior: Essays in Honor of John Vanderkamp, Louis N. Christofides, E. Kenneth Grant, and Robert Swidinsky, eds.(Toronto: University of Toronto Press).

Case, Anne C., Darren H. Lubotsky and Christina P. Paxson. 2002. "Economic Status and Health in Childhood: The Origins of the Gradient." American Economic Review 92 (December): 1308-1334.

Currie, Janet and Mark Stabile. 2003. "Socioeconomic Status and Child Health: Why is the Relationship Stronger for Older Children?” American Economic Review 93 (December): 1813-1823.

Duflo, Esther. 2001. " Schooling and Labor Market Consequences of School Construction in Indonesia: Evidence from an Unusual Policy Experiment." American Economic Review 91 (September): 795-813.

Duflo, Esther. 2004. "The Medium Run Effects of Educational Expansion: Evidence from a Large School Construction Program in Indonesia." Journal of Development Economics 74 (June): 163-197.

Duryea, Suzanne and Mary Arends-Kuenning. 2003. "School Attendance, Child Labor and Local Labor Market Fluctuations in Urban Brazil.” World Development 31 (July): 1165-1178. 
Edmonds, Eric V. and Nina Pavcnik. 2005. "The Effect of Trade Liberalization on Child Labor.” Journal of International Economics 65 (March): 401-419.

Edmonds, Eric V. and Nina Pavcnik. 2006. "Trade Liberalization and the Allocation of Labor between Households and Markets in a Poor Country." Journal of International Economics 69 (July): 272-295.

Emerson, Patrick M. and Andre P. Souza. 2006. "Is Child Labor Harmful: The Impact of Working Earlier in Life on Adult Earnings." Mimeo. University of Colorado at Denver (February).

Fiess, Norbert M. and Dorte Verner. 2003. "Migration and Human Capital in Brazil during the 1990s." Mimeo. World Bank (July).

Gertler, Paul and Paul Glewwe. 1990. "The Willingness to Pay for Education in Developing Countries: Evidence from Rural Peru." Journal of Public Economics 42 (August): 251-275.

Giuffrida, Antonio, Roberto F. Iunes and William D. Savedoff. 2005. "Health and Poverty in Brazil: Estimation by Structural Equation Model with Latent Variables." Mimeo. InterAmerican Development Bank (March)

Graitcer, Philip L. and Leonard B. Lerer. 1998. "Child Labor and Health: Quantifying the Global Health Impacts of Child Labor.” Mimeo. World Bank (November).

Grossman, Michael and R. Kaestner. 1997. "Effects of Education on Health," in J.R.

Behrman and N. Stacey Eds. The Social Benefits of education, University of Michigan Press, Ann Arbor

Gunnarson, Victoria, Peter F. Orazem and Mario Sanchez. 2006. "Child Labor and School Achievement in Latin America." World Bank Economic Review 20 (January): 31-54.

Heady, Christopher. 2003. "What is the Effect of Child Labour on Learning Achievement" World Development 31 (February): 385-398.

Instituto Brasileriro de Geografia Estatistica, (IBGE). 2003. Estatisticas do Seculo XX. Rio de Janeiro: IBGE

International Labour Organisation. 1998. Conference Report VI (1) Child Labor: Targeting the intolerable. Geneva, ILO.

http://www.ilo.org/public/english/standards/ipec/publ/policy/target/index.htm

International Labour Organisation. 1999. Convention 182: Convention on the Worst Forms of Child Labour, Geneva, ILO.

http://www.ilo.org/public/english/standards/ipec/ratification/convention.text.htm 
Kassouf, Ana L., Martin McKee and Elias Mossialos. 2001. "Early Entrance to the Job Market and its Effect on Adult Health: Evidence from Brazil." Health Policy and Planning 16 (January): 21-28.

Lleras-Muney, Adriana. 2005. "The Relationship Between Education and Adult Mortality in the United States." Review of Economic Studies 72 (January): 189-221.

O'Donnell, Owen, Furio C. Rosati and Eddy van Doorslaer. 2005. "Health Effects of Child Work: Evidence from Rural Vietnam." Journal of Population Economics 18(July): 437-467.

Orazem, Peter F., Guilherme Sedlacek and Zafiris Tzannatos. 2009. Child Labor and Education in Latin America: An Economic Perspective New York: Palgrave Macmillan.

Patrinos, Harry A., and George Psacharopoulos. 1997. "Family Size, Schooling and Child Labor in Peru - An Empirical Analysis." Journal of Population Economics 10 (October): 387-405.

Post, David, and Suet-ling Pong. 2000. "Employment During Middle School: The Effects on Academic Achievement in the U.S. and Abroad." Educational Evaluation and Policy Analysis 22 (Fall): 273-298.

Psacharopoulos, George, 1997. "Child Labor versus Educational Attainment: Some Evidence from Latin America.” Journal of Population Economics 10 (October): 377-386.

Ravallion, Martin, and Quentin Wodon. 2000. "Does Child Labor Displace Schooling? Evidence on Behavioral Responses to an Enrollment Subsidy." The Economic Journal 110: C158-C175.

Rosati, Furio C. and Mariacristina Rossi. 2003. "Children's Working Hours and School Enrollment: Evidence From Pakistan and Nicaragua." The World Bank Economic Review 17 (2): 283-295.

Rosati, Furio C. and Roland Straub. 2004. "Does Work during Childhood Affect Adult's Health? An Analysis for Guatemala." UCW Working Paper (March).

Rosenzweig, Mark R. 1980 "Neoclassical Theory and the Optimizing Peasant: An Econometric Analysis of Market Family Labor Supply in a Developing Country," Quarterly Journal of Economics 94 (February): 31-55.

Satyanarayana, K., Krishna T.P. and Rao BS. 1986. "Effect of Early Childhood Undernutrition and Child Labour on Growth and Adult Nutritional Status of Rural Indian Boys around Hyderabad." Human Nutrition and Clinical Nutrition 40(2): 131-139.

Van Doorslaer, Eddy. 1987. Health, Knowledge and the demand for medical care, Maastricht, Assen. 
Wagstaff, Adam 1993. “ The Demand for Health: An Empirical Reformulation of the Grossman Model. Health Economics 2: 189-198. 
Figure 1. Age of labor market entry and self reported adult health conditions in Brazil by age cohort (Source: Authors' compilation based on data from the 1998 PNAD)

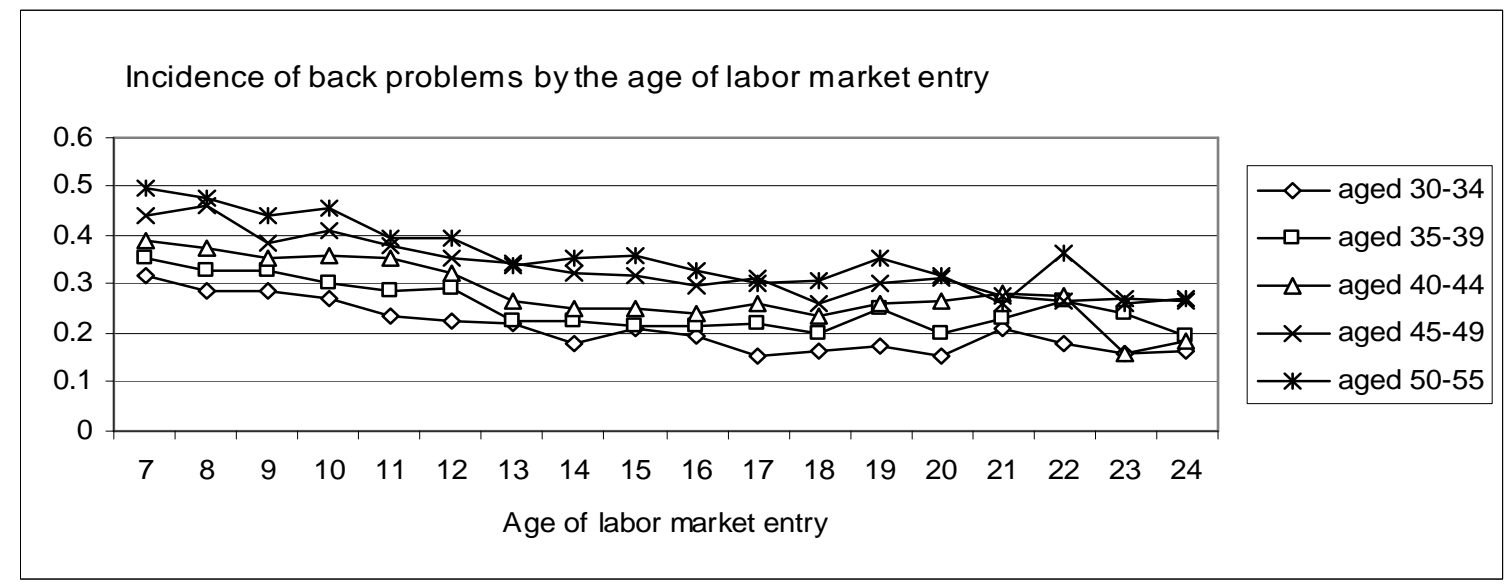

Incidence of arthritis by the age of labor market entry

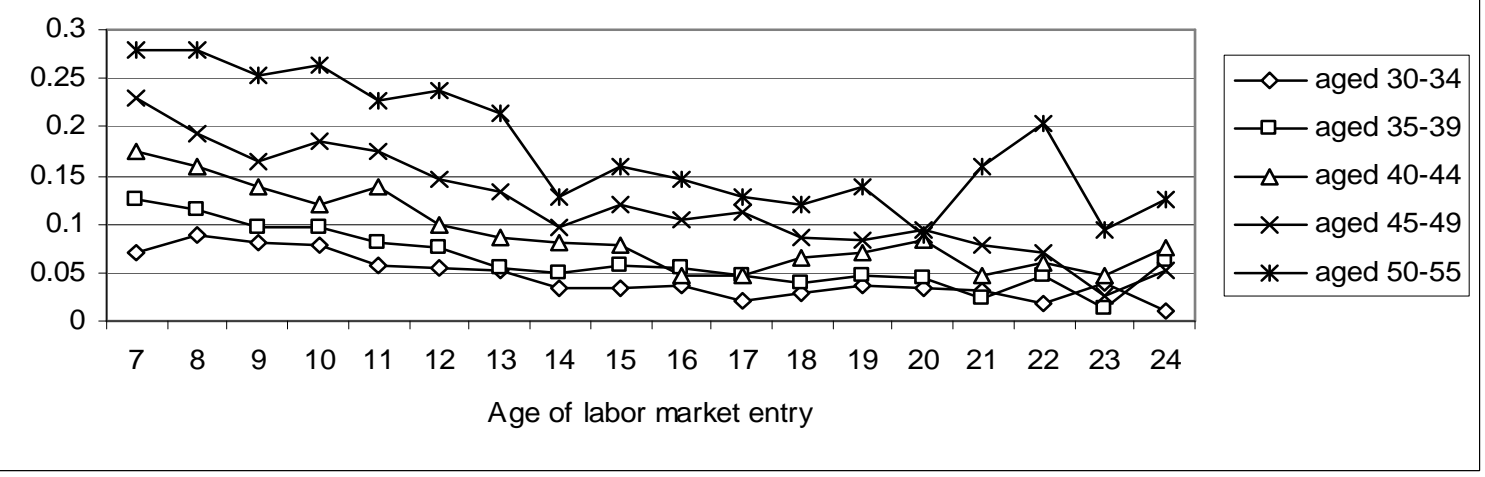

Incidence of hypertension by the age of labor market entry

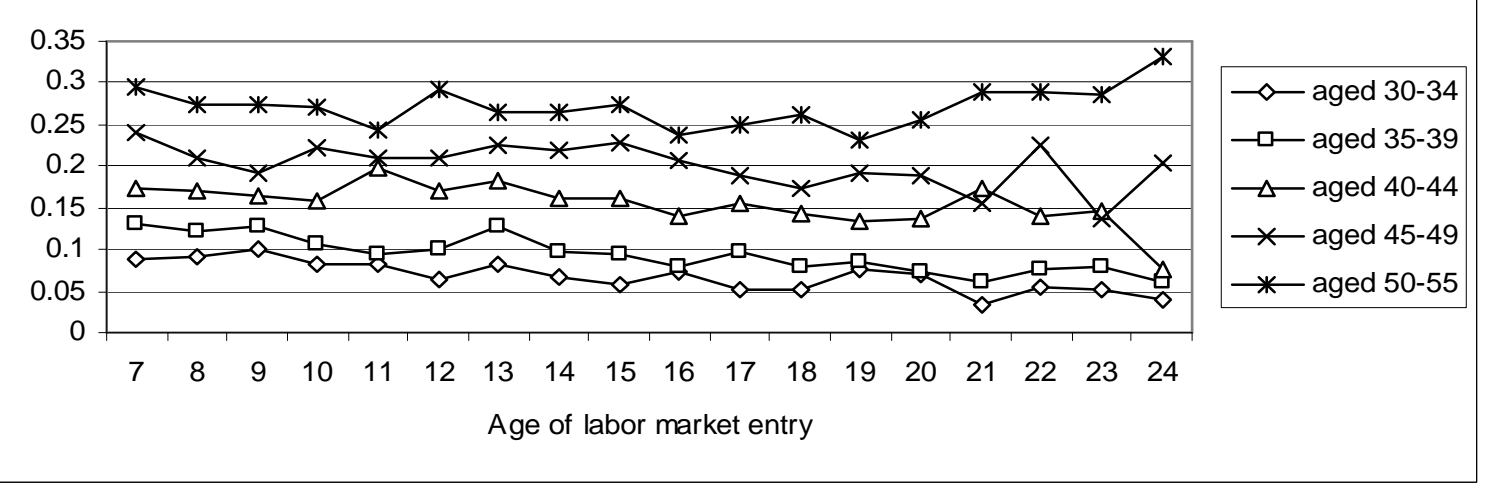


Figure 2a. Schools per 1000 children by year cohort was age 7: Brazil and selected states

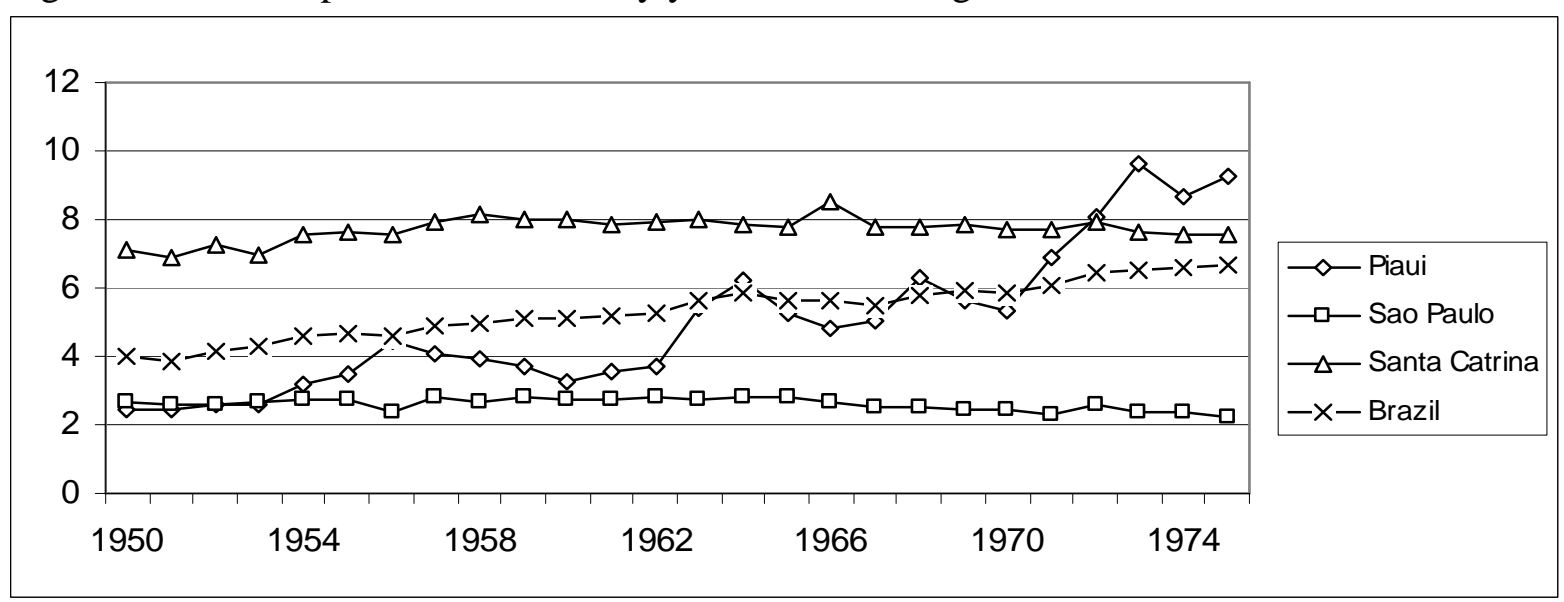

Figure $2 \mathrm{~b}$. Teachers per 1000 children by year cohort was age 7: Brazil and selected states

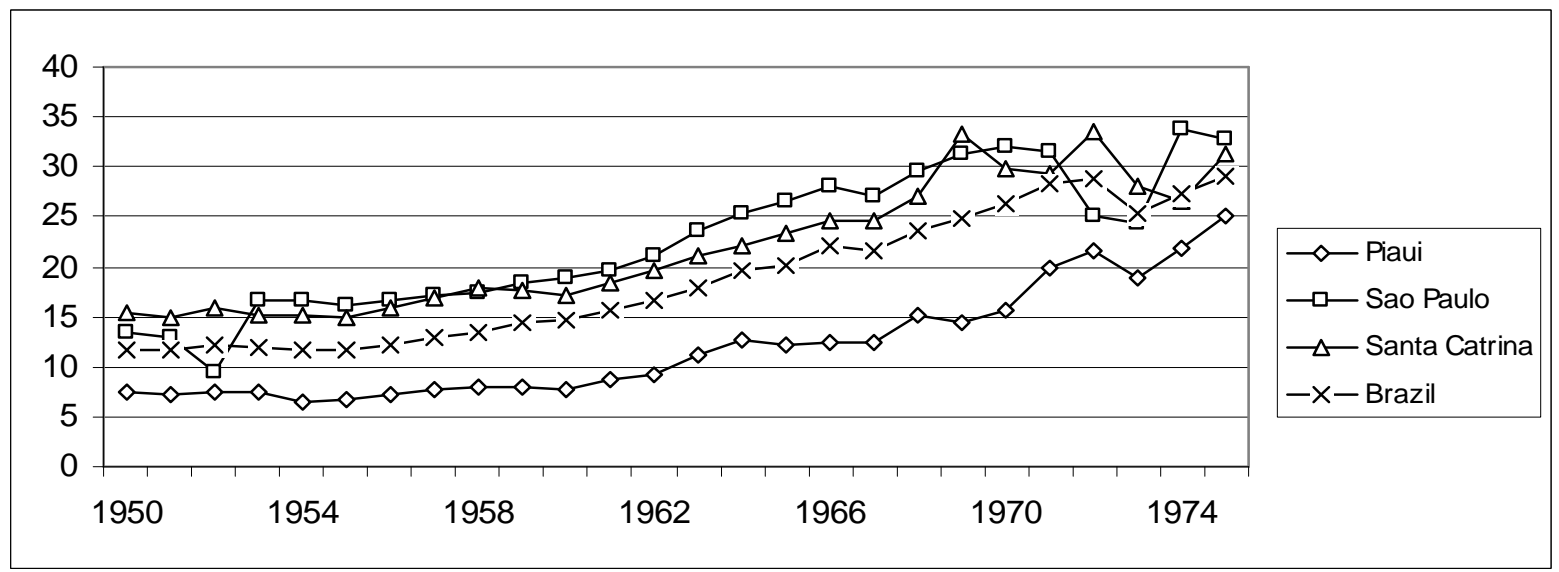

Figure 2c. Average wage rate (in thousands of 2000 Reals) for workers with less than 5 years of schooling by year cohort was age 12: Brazil and selected states

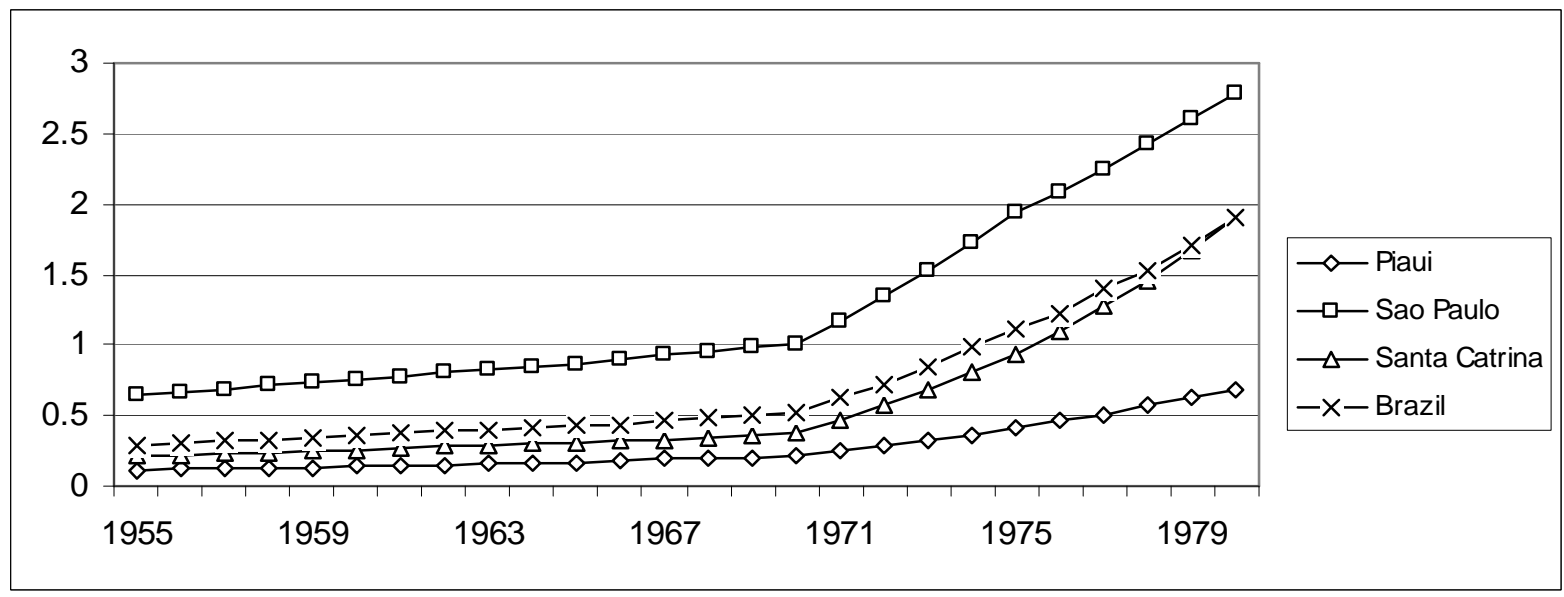


Figure 3. Distribution: Age of labor market entry (\%)

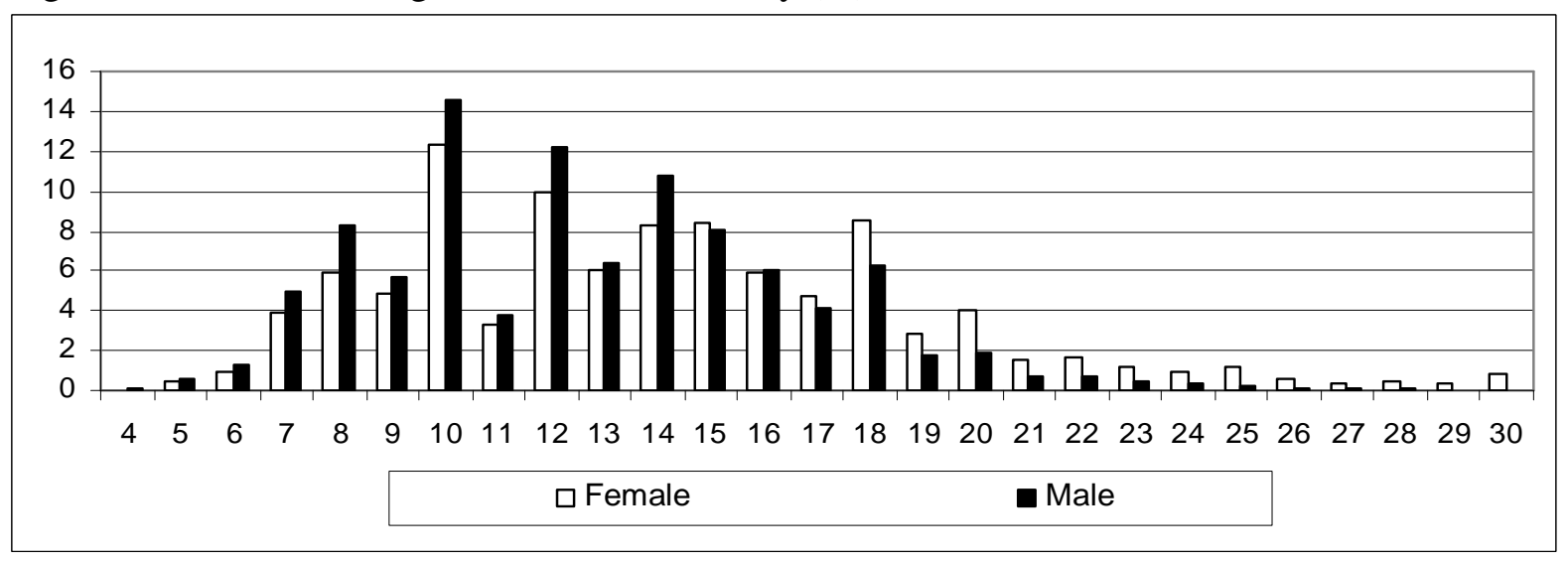

Figure 4. Distribution: Years of schooling completed (\%)

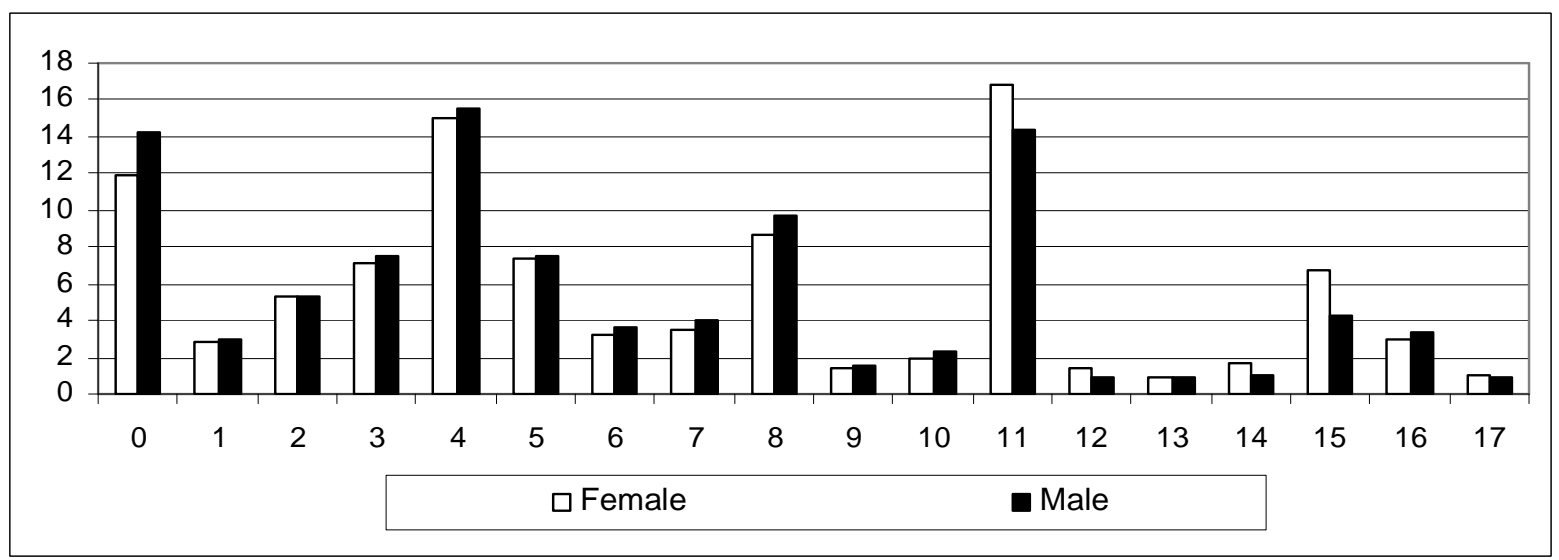

Figure 5. Average years of schooling completed and age of labor market entry by birth cohort

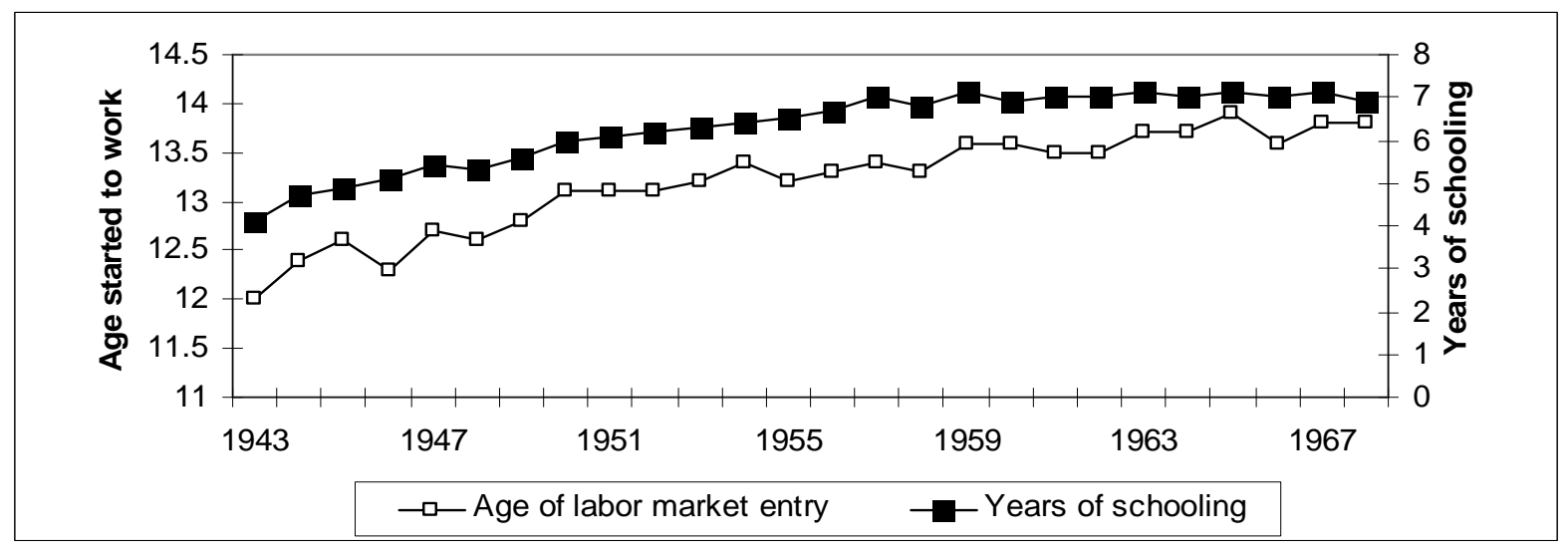


Figure 6: Comparison of Probit (table 2) and IV (Table 5) estimates of the effect of delaying labor market entry by one year on probability of health problems as an adult

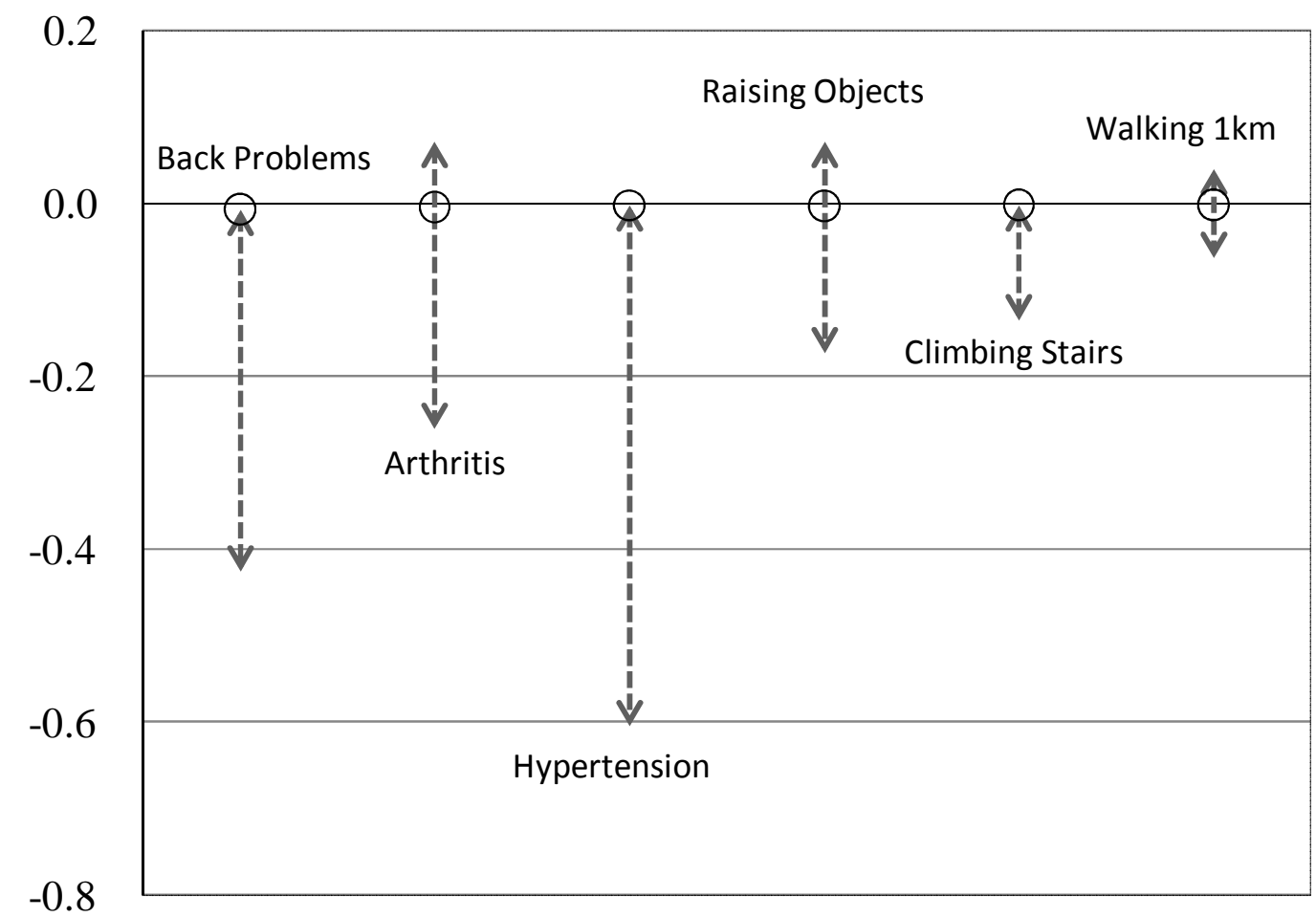

The Probit estimate of the health effect of delaying labor market entry is indicated by $\mathrm{O}$. The $95 \%$ confidence interval of the corresponding instrumental variable estimate is indicated by the hatched line. 
Table 1. Summary statistics

\begin{tabular}{|c|c|c|c|c|c|c|c|c|}
\hline \multirow[b]{2}{*}{ Variables } & \multicolumn{4}{|c|}{$\begin{array}{l}\text { Pooled sample } \\
\quad(n=67927)\end{array}$} & \multicolumn{2}{|c|}{$\begin{array}{c}\text { Female } \\
(\mathrm{n}=28043)\end{array}$} & \multicolumn{2}{|c|}{$\begin{array}{c}\text { Male } \\
(\mathrm{n}=39884)\end{array}$} \\
\hline & Mean & $\begin{array}{l}\text { Std. } \\
\text { Dev. }\end{array}$ & Min & $\operatorname{Max}$ & Mean & $\begin{array}{l}\text { Std. } \\
\text { Dev. }\end{array}$ & Mean & $\begin{array}{l}\text { Std. } \\
\text { Dev. }\end{array}$ \\
\hline Age started to work & 13.3 & 4.4 & 4 & 30 & 14.1 & 4.9 & 12.7 & 3.9 \\
\hline Years of schooling & 6.5 & 4.7 & 0 & 17 & 6.8 & 4.8 & 6.3 & 4.7 \\
\hline Male & .587 & .492 & 0 & 1 & & & & \\
\hline Age & 40.7 & 7.0 & 30 & 55 & 40.4 & 6.9 & 40.9 & 7.0 \\
\hline Black & .061 & .239 & 0 & 1 & .060 & .238 & .061 & .239 \\
\hline Mixed & .392 & 488 & 0 & 1 & .388 & .487 & .394 & .489 \\
\hline Other race & .006 & .078 & 0 & 1 & .006 & .079 & .006 & .077 \\
\hline age3036 & .334 & 472 & 0 & 1 & .344 & .475 & .328 & .469 \\
\hline age 3743 & .318 & 466 & 0 & 1 & .326 & 469 & .312 & .463 \\
\hline age4449 & .207 & .405 & 0 & 1 & .202 & .401 & .211 & .408 \\
\hline age 5055 & .140 & .347 & 0 & 1 & .129 & .335 & .148 & .355 \\
\hline \multicolumn{9}{|l|}{ Chronic Disease } \\
\hline Back problems & .296 & .456 & 0 & 1 & .326 & 469 & .274 & 446 \\
\hline Arthritis & .104 & .305 & 0 & 1 & 137 & .343 & .080 & .272 \\
\hline Cancer & .002 & .044 & 0 & 1 & .003 & .052 & .001 & .037 \\
\hline Diabetes & .020 & .139 & 0 & 1 & .022 & .147 & .018 & .133 \\
\hline Asthma & .030 & .170 & 0 & 1 & .037 & .189 & .024 & .155 \\
\hline Hypertension & .150 & .357 & 0 & 1 & .183 & .387 & .126 & .332 \\
\hline Heart disease & .040 & 196 & 0 & 1 & .050 & .219 & .032 & .177 \\
\hline Kidney disease & .042 & 200 & 0 & 1 & .042 & .200 & .042 & .200 \\
\hline Depression & .070 & .254 & 0 & 1 & .111 & .314 & .040 & .197 \\
\hline Tuberculosis & .001 & .034 & 0 & 1 & .001 & .029 & .001 & .037 \\
\hline Tendonitis & .031 & .173 & 0 & 1 & .046 & .208 & .021 & .143 \\
\hline Cirrhosis & .002 & .047 & 0 & 1 & .001 & .033 & .003 & .055 \\
\hline \multicolumn{9}{|l|}{ Functional Limitation } \\
\hline Raising objects & .086 & .281 & 0 & 1 & .114 & .318 & .067 & .249 \\
\hline Pushing and carrying & .017 & .130 & 0 & 1 & .026 & .160 & .011 & .104 \\
\hline Climbing stairs & .041 & 198 & 0 & 1 & .062 & 241 & .026 & .158 \\
\hline Bending down & .039 & 193 & 0 & 1 & .053 & .224 & .029 & .167 \\
\hline Walking 1km & .029 & 167 & 0 & 1 & .042 & .200 & .020 & .139 \\
\hline Walking $100 \mathrm{~m}$ & .004 & .063 & 0 & 1 & .005 & .072 & .003 & .056 \\
\hline \multicolumn{9}{|l|}{ Instruments } \\
\hline Schools per thousand children at age 7 & 5.5 & 1.8 & 1.4 & 11.9 & 5.6 & 1.8 & 5.5 & 1.8 \\
\hline Teachers per thousand children at age 7 & 20.1 & 8.5 & 5.1 & 51.6 & 20.3 & 8.6 & 20.0 & 8.5 \\
\hline Lower-skilled worker's wage at age 12 & .79 & .58 & .11 & 3.18 & .80 & .58 & .79 & .58 \\
\hline
\end{tabular}


Table 2. Probit estimates of age started to work, years of schooling and other control variables on the incidence of selected chronic ailments

\begin{tabular}{|c|c|c|c|c|c|c|}
\hline Variables & $\begin{array}{l}\text { Back } \\
\text { Problems }\end{array}$ & Arthritis & Hypertension & $\begin{array}{l}\text { Raising } \\
\text { Objects }\end{array}$ & Climbing stairs & Walking $1 \mathrm{~km}$ \\
\hline Age started to work & $\begin{array}{l}-.0067 * * * \\
(.0005)\end{array}$ & $\begin{array}{l}-.0040 * * * \\
(.0003)\end{array}$ & $\begin{array}{l}-.0018 * * * \\
(.0004)\end{array}$ & $\begin{array}{l}-.0029 * * * \\
(.0003)\end{array}$ & $\begin{array}{l}-.0014 * * * \\
(.0002)\end{array}$ & $\begin{array}{l}-.0010 * * * \\
(.0002)\end{array}$ \\
\hline Years of schooling & $\begin{array}{l}-.0107 * * * \\
(.0004)\end{array}$ & $\begin{array}{l}-.0066 * * * \\
(.0003)\end{array}$ & $\begin{array}{l}-.0029 * * * \\
(.0003)\end{array}$ & $\begin{array}{l}-.0042 * * * \\
(.0003)\end{array}$ & $\begin{array}{l}-.0020 * * * \\
(.0002)\end{array}$ & $\begin{array}{l}-.0014 * * * \\
(.0001)\end{array}$ \\
\hline Age 3036 & $\begin{array}{l}-.1353 * * * \\
(.0050)\end{array}$ & $\begin{array}{l}-.0963 * * * \\
(.0024)\end{array}$ & $\begin{array}{l}-.1538 * * * \\
(.0031)\end{array}$ & $\begin{array}{l}-.0769 * * * \\
(.0023)\end{array}$ & $\begin{array}{l}-.0359 * * * \\
(.0014)\end{array}$ & $\begin{array}{l}-.0236 * * * \\
(.0013)\end{array}$ \\
\hline Age 3743 & $\begin{array}{l}-.0817 * * * \\
(.0052)\end{array}$ & $\begin{array}{l}-.0658 * * * \\
(.0024)\end{array}$ & $\begin{array}{l}-.0940 * * * \\
(.0032)\end{array}$ & $\begin{array}{l}-.0515 * * * \\
(.0023)\end{array}$ & $\begin{array}{l}-.0223 * * * \\
(.0014)\end{array}$ & $\begin{array}{l}-.0154 * * * \\
(.0013)\end{array}$ \\
\hline Age4449 & $\begin{array}{l}-.0309 * * * \\
(.0057)\end{array}$ & $\begin{array}{l}-.0324 * * * \\
(.0025)\end{array}$ & $\begin{array}{l}-.0421 * * * \\
(.0035)\end{array}$ & $\begin{array}{l}-.0226 * * * \\
(.0025)\end{array}$ & $\begin{array}{l}-.0080 * * * \\
(.0015)\end{array}$ & $\begin{array}{l}-.0057 * * * \\
(.0014)\end{array}$ \\
\hline Male & $\begin{array}{l}-.0698 * * * \\
(.0075)\end{array}$ & $\begin{array}{l}-.0617 * * * \\
(.0023)\end{array}$ & $\begin{array}{l}-.0627 * * * \\
(.0028)\end{array}$ & $\begin{array}{l}-.0524 * * * \\
(.0022)\end{array}$ & $\begin{array}{l}-.0361 * * * \\
(.0015)\end{array}$ & $\begin{array}{l}-.0222 * * * \\
(.0013)\end{array}$ \\
\hline Black & $\begin{array}{l}-.0213 * * * \\
(.0075)\end{array}$ & $\begin{array}{l}-.0049 \\
(.0044)\end{array}$ & $\begin{array}{l}.0572 * * * \\
(.0067)\end{array}$ & $\begin{array}{l}-.0082 * \\
(.0041)\end{array}$ & $\begin{array}{l}.0006 \\
(.0028)\end{array}$ & $\begin{array}{l}-.0016 \\
(.0023)\end{array}$ \\
\hline Mixed & $\begin{array}{l}.0050 \\
(.0042)\end{array}$ & $\begin{array}{l}.0062 * * * \\
(.0025)\end{array}$ & $\begin{array}{l}.0169 * * * \\
(.0032)\end{array}$ & $\begin{array}{l}.0066^{* * * *} \\
(.0024)\end{array}$ & $\begin{array}{l}.0045^{* * *} \\
(.0015)\end{array}$ & $\begin{array}{l}.0050 * * * \\
(.0013)\end{array}$ \\
\hline Other race & $\begin{array}{l}-.0227 \\
(.0230)\end{array}$ & $\begin{array}{l}.0036 \\
(.0152)\end{array}$ & $\begin{array}{l}.0020 \\
(.0176)\end{array}$ & $\begin{array}{l}-.0186 \\
(.0116)\end{array}$ & $\begin{array}{l}-.0106 \\
(.0068)\end{array}$ & $\begin{array}{l}-.0155^{* *} \\
(.0042)\end{array}$ \\
\hline $\begin{array}{l}\text { Joint effect of child labor } \\
\text { and schooling with } \chi^{2}(1) \\
\text { statistic in brackets }\end{array}$ & $\begin{array}{l}-0.017 * * * \\
{[223.4]}\end{array}$ & $\begin{array}{l}-0.011 * * * \\
{[652.4]}\end{array}$ & $\begin{array}{l}-0.005^{* * * *} \\
{[26.5]}\end{array}$ & $\begin{array}{l}-0.007 * * * \\
{[179.9] * * *}\end{array}$ & $\begin{array}{l}-0.003 * * * \\
{[139.6]}\end{array}$ & $\begin{array}{l}-0.002 * * * \\
{[130.6]}\end{array}$ \\
\hline $\begin{array}{l}\text { Exclusion test of child labor } \\
\text { and schooling }\end{array}$ & $\chi^{2}(2)=224 * * *$ & $\chi^{2}(2)=653^{* * *}$ & $\chi^{2}(2)=29 * * *$ & $\chi^{2}(2)=180^{* * *}$ & $\chi^{2}(2)=144^{* * *}$ & $\chi^{2}(2)=142^{* * *}$ \\
\hline Pseudo R2 & .0424 & .1098 & .0589 & .0725 & .0867 & .0662 \\
\hline $\mathrm{N}$ & 67927 & 67901 & 67927 & 67901 & 67901 & 67741 \\
\hline
\end{tabular}

Notes: Marginal probabilities are reported rather than probit coefficients. These regressions also include dummy variables for state of birth. Robust standard errors are reported in parentheses. *** Significant at $1 \%$ level, ** Significant at 5\% level, * Significant at $10 \%$ level 
Table 3. Probit estimates of the health consequences of age started to work and years of schooling on selected chronic ailments

\begin{tabular}{|c|c|c|c|}
\hline Variables & Asthma & Bending down & Heart disease \\
\hline Age started to work & $-.0003 *$ & $-.0016 * * *$ & $-.0007 * * *$ \\
\hline Years of schooling & $\begin{array}{l}(.0002) \\
-.0001 \\
(.0002)\end{array}$ & $\begin{array}{l}(.0002) \\
-.0016 * * * \\
(.0002)\end{array}$ & $\begin{array}{l}(.0002) \\
-.0008 * * * \\
(.0002)\end{array}$ \\
\hline $\begin{array}{l}\text { Joint effect of child labor and } \\
\text { schooling with } \chi^{2}(1) \text { statistic in } \\
\text { brackets }\end{array}$ & $\begin{array}{l}-0.0004 * * \\
{[3.95]}\end{array}$ & $\begin{array}{l}-0.004 * * * \\
{[158]}\end{array}$ & $\begin{array}{l}-0.002 * * * \\
{[22.6]}\end{array}$ \\
\hline $\begin{array}{l}\text { Exclusion test of child labor and } \\
\text { schooling }\end{array}$ & $6.57 * *$ & $167 * * *$ & $29.2 * * *$ \\
\hline Pseudo R2 & .0151 & .0760 & .0470 \\
\hline $\mathrm{N}$ & 67901 & 67857 & 67857 \\
\hline Variables & Kidney disease & Depression & Tendonitis \\
\hline Age started to work & $\begin{array}{l}-.0018 * * * \\
(.0002)\end{array}$ & $\begin{array}{l}-.0022 * * * \\
(.0002)\end{array}$ & $\begin{array}{l}-.0003 * * \\
(.0002)\end{array}$ \\
\hline Years of schooling & $\begin{array}{l}-.0023 * * * \\
(.0002)\end{array}$ & $\begin{array}{l}-.0006 * * * \\
(.0002)\end{array}$ & $\begin{array}{l}.0012 * * * \\
(.0001)\end{array}$ \\
\hline $\begin{array}{l}\text { Joint effect of child labor and } \\
\text { schooling with } \chi^{2}(1) \text { statistic in } \\
\text { brackets }\end{array}$ & $\begin{array}{l}-0.004 * * * \\
{[218]}\end{array}$ & $\begin{array}{l}-0.003 * * * \\
{[76.2]}\end{array}$ & $\begin{array}{l}0.001 * * * \\
{[7.1]}\end{array}$ \\
\hline $\begin{array}{l}\text { Exclusion test of child labor and } \\
\text { schooling }\end{array}$ & $227 * * *$ & $136 * * *$ & $31.5 * * *$ \\
\hline Pseudo R2 & .0386 & .0504 & .0424 \\
\hline $\mathrm{N}$ & 67927 & 67867 & 67857 \\
\hline
\end{tabular}

Notes: Specification is the same as that used in Table 2, but only a subset of estimates are reported. Marginal probabilities are reported rather than probit coefficients. See Table 2 for other details. 
Table 4. IV Estimates-first stage regression of age of labor market entry and years of schooling completed

\begin{tabular}{|c|c|c|}
\hline \multirow{2}{*}{$\begin{array}{l}\text { Variables } \\
\text { Age3036 }\end{array}$} & Age started to work & Years of schooling \\
\hline & $\begin{array}{c}.673 * * * \\
(.112)\end{array}$ & $\begin{array}{c}1.567 * * * \\
(.115)\end{array}$ \\
\hline Age3743 & $\begin{array}{c}.672 * * * \\
(.079)\end{array}$ & $\begin{array}{l}1.561 * * * \\
(.113)\end{array}$ \\
\hline Age4449 & $\begin{array}{l}.553 * * * \\
(.055)\end{array}$ & $\begin{array}{l}.998 * * * \\
(.074)\end{array}$ \\
\hline Male & $\begin{array}{c}-1.369 * * * \\
(.059)\end{array}$ & $\begin{array}{c}-.496 * * * \\
(.063)\end{array}$ \\
\hline Black & $\begin{array}{l}-1.013^{* * * *} \\
\quad(.194)\end{array}$ & $\begin{array}{c}-2.637 * * * \\
(.236)\end{array}$ \\
\hline Mixed & $\begin{array}{l}-1.080 * * * \\
(.065)\end{array}$ & $\begin{array}{l}-2.255^{* * *} \\
(.085)\end{array}$ \\
\hline Other race & $\begin{array}{l}.304 \\
(.456)\end{array}$ & $\begin{array}{l}1.325 \\
(.822)\end{array}$ \\
\hline \multicolumn{3}{|l|}{ Instruments } \\
\hline Schools per thousand children at age 7 & $\begin{array}{l}.053 * * \\
(.023)\end{array}$ & $\begin{array}{l}.063 * * * \\
(.022)\end{array}$ \\
\hline Teachers per thousand children at age 7 & $\begin{array}{l}.018 * * * \\
(.005)\end{array}$ & $\begin{array}{l}.014^{*} \\
(.009)\end{array}$ \\
\hline Lower-skilled worker's wage at age 12 & $\begin{array}{r}.137 * * \\
(.063)\end{array}$ & $\begin{array}{l}.065 \\
(.119)\end{array}$ \\
\hline Intercept & $\begin{array}{c}15.58 * * * \\
(.102)\end{array}$ & $\begin{array}{c}7.77 * * * \\
(.129)\end{array}$ \\
\hline Test of Excluded Instruments F $(3,24)$ & $12.3 * * *$ & $9.2 * * *$ \\
\hline $\begin{array}{l}\text { R-Squared } \\
\mathrm{N}\end{array}$ & $\begin{array}{l}.081 \\
67927\end{array}$ & $\begin{array}{l}.138 \\
67927\end{array}$ \\
\hline
\end{tabular}

Notes: Regression also includes dummy variables for state of birth. Clustered robust standard errors are reported in parentheses.

*** Significant at 1\% level, ** Significant at 5\% level, * Significant at $10 \%$ level. 
Table 5. IV regressions of the incidence of selected chronic ailments

\begin{tabular}{|c|c|c|c|c|c|c|}
\hline Variables & Back Problems & Arthritis & Hypertension & Raising objects & Climbing stairs & Walking $1 \mathrm{~km}$ \\
\hline \multirow[t]{2}{*}{ Age started to work } & -.2337 & -.0939 & -.4380 & -.0504 & -.0719 & -.0110 \\
\hline & $(1.57)$ & $(.99)$ & $(1.62)$ & $(.75)$ & (1.39) & $(.23)$ \\
\hline \multirow[t]{2}{*}{ Years of schooling } & .0772 & -.0151 & .3091 & -.0387 & .0288 & -.0251 \\
\hline & $(.42)$ & $(.41)$ & $(.99)$ & $(.56)$ & $(.46)$ & $(.67)$ \\
\hline \multirow[t]{2}{*}{ Age 3036} & -.0428 & .0064 & -.2226 & .0367 & -.0197 & .0373 \\
\hline & $(.22)$ & $(.23)$ & $(.82)$ & $(.47)$ & $(.33)$ & $(.77)$ \\
\hline \multirow[t]{2}{*}{ Age 3743} & -.0749 & .0214 & -.2047 & .0509 & -.0151 & .0429 \\
\hline & $(.14)$ & $(.41)$ & $(.77)$ & $(.63)$ & $(.24)$ & $(.85)$ \\
\hline \multirow[t]{2}{*}{ Age4449 } & .0621 & .0317 & -.0879 & .0482 & .0025 & .0337 \\
\hline & $(.21)$ & $(.75)$ & $(.56)$ & $(1.02)$ & $(.11)$ & (1.19) \\
\hline \multirow[t]{2}{*}{ Male } & $-.3407 * * *$ & $-.2238 * * *$ & $-.5835 * *$ & $-.1547 * *$ & $-.1780 * * *$ & $-.0587 *$ \\
\hline & $(2.71)$ & $(2.71)$ & $(2.22)$ & $(2.43)$ & (2.69) & $(1.73)$ \\
\hline \multirow[t]{2}{*}{ Black } & -.0205 & -.0751 & .6672 & -.0770 & .0114 & -.0208 \\
\hline & $(.09)$ & $(.97)$ & $(.75)$ & (1.13) & $(.06)$ & $(1.15)$ \\
\hline \multirow[t]{2}{*}{ Mixed } & -.0424 & -.1016 & .2832 & -.1114 & -.0022 & -.0250 \\
\hline & $(.20)$ & $(1.11)$ & $(.57)$ & $(1.22)$ & $(.06)$ & $(1.28)$ \\
\hline \multirow[t]{2}{*}{ Other race } & -.0661 & .0530 & -.1285 & .0492 & -.0209 & -.0091 \\
\hline & $(.35)$ & $(.67)$ & $(.80)$ & $(.52)$ & $(.46)$ & $(.51)$ \\
\hline Joint effect of child labor & $-0.157 * * *$ & $-0.109 * * *$ & -0.129 & $-0.089 * * *$ & $-0.043 * *$ & $-0.036 * * *$ \\
\hline $\begin{array}{l}\text { and schooling with } \chi^{2}(1) \\
\text { statistic in brackets }\end{array}$ & [7.91] & [16.4] & {$[1.50]$} & [14.6] & {$[5.70]$} & {$[9.52]$} \\
\hline $\begin{array}{l}\text { Exclusion test of child } \\
\text { labor and schooling }\end{array}$ & $\chi^{2}(2)=14.1 * * *$ & $\chi^{2}(2)=20.8^{* * *}$ & $\chi^{2}(2)=5.8^{*}$ & $\chi^{2}(2)=17.9 * * *$ & $\chi^{2}(2)=10.0 * * *$ & $\chi^{2}(2)=10.5^{* * *}$ \\
\hline Overidentification test & $\operatorname{Chi} 2(1)=3.06$ & Chi2(1)=.28 & Chi2(1)=.21 & Chi2 $(1)=.86$ & Chi2(1) $=.05$ & $\operatorname{Chi} 2(1)=.08$ \\
\hline Pseudo R2 & .0273 & .0810 & .0579 & .0567 & .0713 & .0521 \\
\hline $\mathrm{N}$ & 67927 & 67901 & 67927 & 67901 & 67901 & 67741 \\
\hline
\end{tabular}

Notes: Marginal probabilities are reported rather than probit coefficients. Regression also includes dummy variables for state of birth.

|Z| statistics from the initial estimation using Newey's minimum chi square estimators are reported in parentheses.

$* * *$ Significant at $1 \%$ level, ** Significant at 5\% level, * Significant at $10 \%$ level.

The Amemiya-Lee-Newey test results for overidentification of instruments were generated using Baum, Schaffer, Stillman and Wiggins'(2006) overid.ado

program for Stata.9. The overidentification test and joint test is distributed chi2(1) with a critical value of 3.84 at the .10 significance level. 
Table 6 IV Estimates-second stage regression on incidence of various chronic ailments

\begin{tabular}{lccc}
\hline \hline Variables & Asthma & Bending down & Heart \\
\hline Age started to work & .0481 & -.0484 & -.1006 \\
Years of schooling & $(1.11)$ & $(.96)$ & $(1.43)$ \\
& -.0523 & .0134 & .0642 \\
\hline Joint effect of child labor and & $(.72)$ & $. .34)$ & $.79)$ \\
schooling with $\chi^{2}(1)$ statistic in & -0.004 & $-0.035^{* * *}$ & -0.042 \\
brackets & {$[0.05]$} & {$[14.2]$} & {$[1.91]$} \\
Exclusion test of child labor and & $\chi^{2}(2)=1.24$ & $\chi^{2}(2)=18.3 * * *$ & $\chi^{2}(2)=5.5^{*}$ \\
schooling & $\chi^{2}(1)=.18$ & $\chi^{2}(1)=2.08$ & $\chi^{2}(1)=.25$ \\
Overidentification test & .0150 & .0623 & .0451 \\
\hline Pseudo R2 & 67901 & 67857 & 67857 \\
$\mathrm{~N}$ & Kidney & Depression & Tendonitis \\
\hline & -.0187 & -.1264 & .0307 \\
\hline Age started to work & $. .42)$ & $(1.24)$ & $(.84)$ \\
& -.0061 & .1382 & -.0410 \\
Years of schooling & $(.29)$ & $(1.17)$ & $(.96)$ \\
& $-0.025^{* *}$ & 0.012 & -0.010 \\
Joint effect of child labor and & {$[4.29]$} & {$[0.10]$} & {$[0.58]$} \\
schooling $\chi^{2}(1)$ statistic in & & & \\
brackets & $\chi^{2}(2)=5.29 *$ & $\chi^{2}(2)=1.55$ & $\chi^{2}(2)=0.98$ \\
Exclusion test of child labor and & $\chi^{2}(1)=.33$ & $\chi^{2}(1)=.04$ & $\chi^{2}(1)=.44$ \\
schooling & .0216 & .0465 & .0386 \\
Overidentification test & 67927 & 67867 & 67857 \\
\hline Pseudo R2 & $\mathrm{N}$ &
\end{tabular}

Notes: Specification is the same as that used in Table 2, but only a subset of estimates are reported. Marginal probabilities are reported rather than probit coefficients. See Table 2 for other details.

*** Significant at 1\% level, ** Significant at 5\% level, * Significant at $10 \%$ level. 
Appendix 1. Age of labor market entry and self reported adult health conditions in Brazil by age cohort (Source: Authors' compilation based on data from the 1998 PNAD)

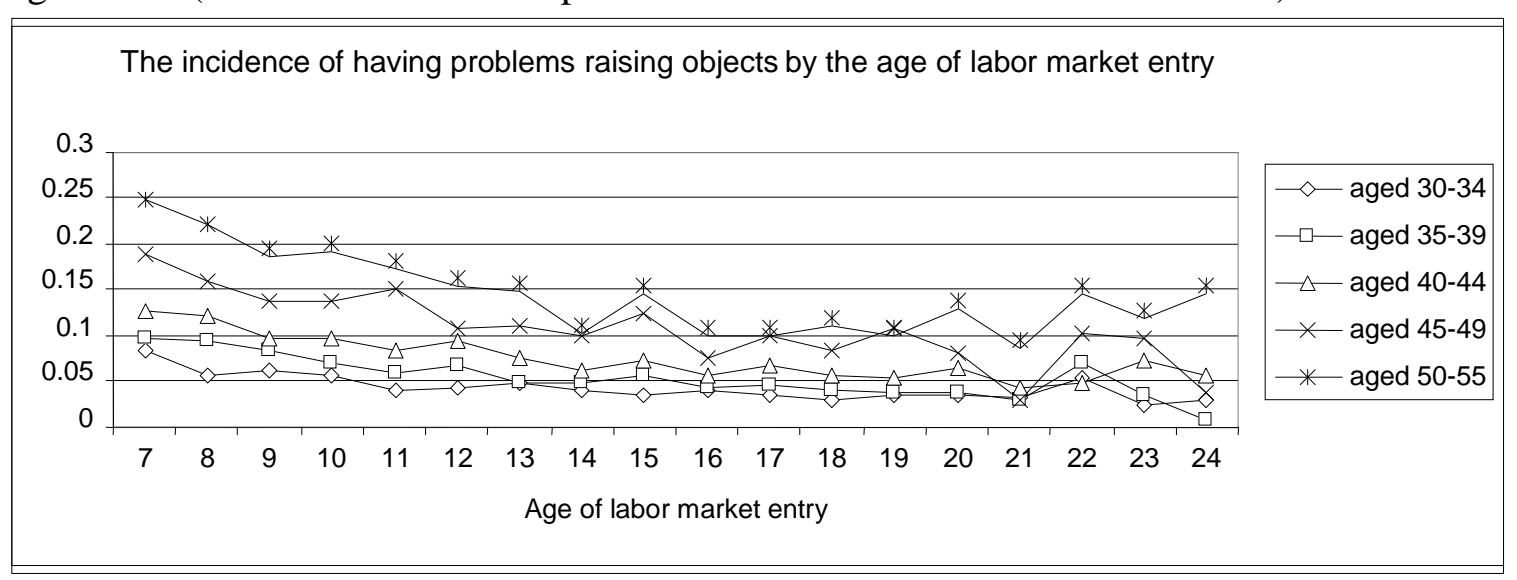

The incidence of having problems climbing stairsby the age of labor market entry
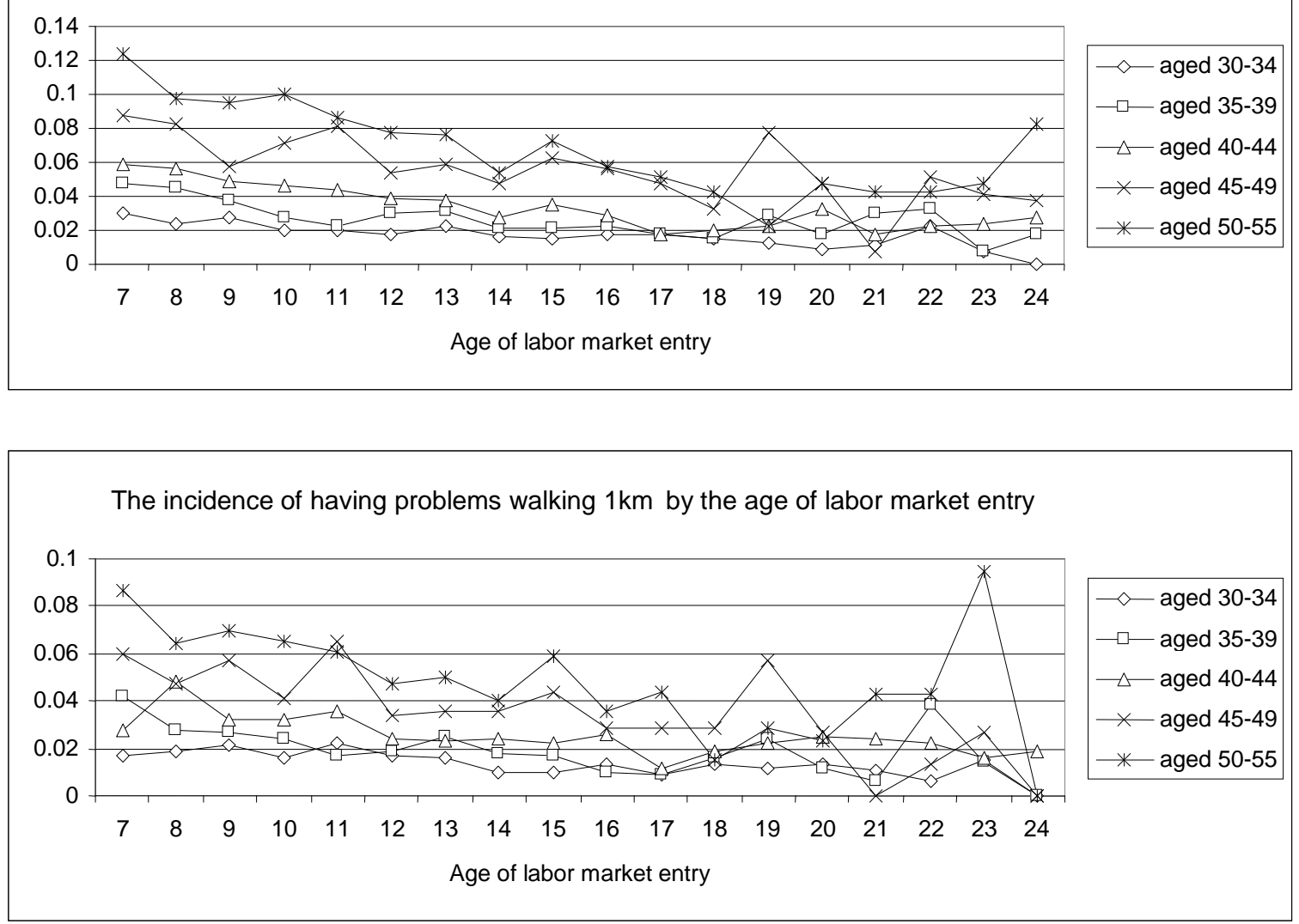
Appendix 1. (continued)

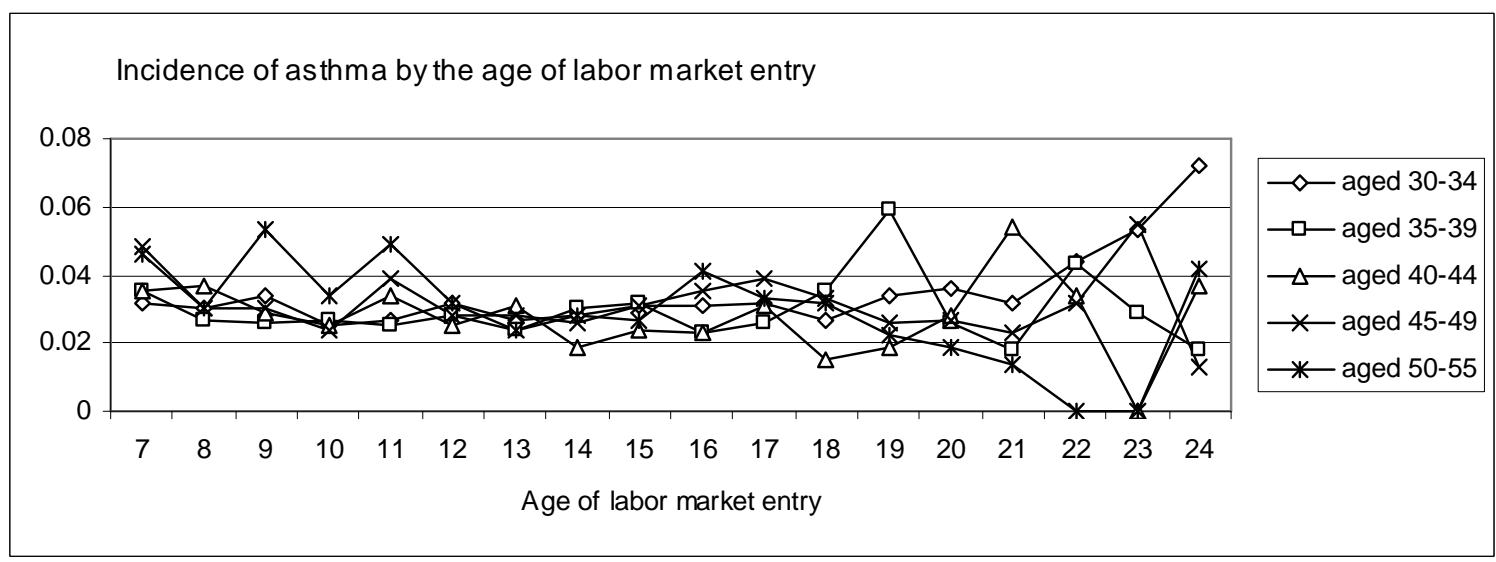

The incidence of having problems bending down by the age of labor market entry

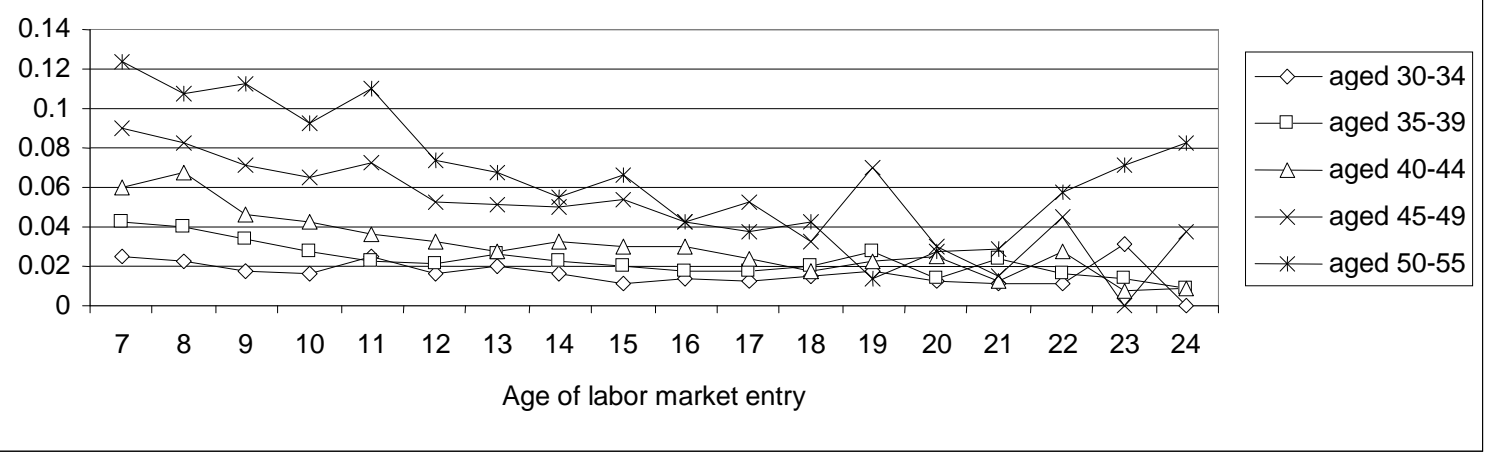

Incidence of heart disease by the age of labor market entry

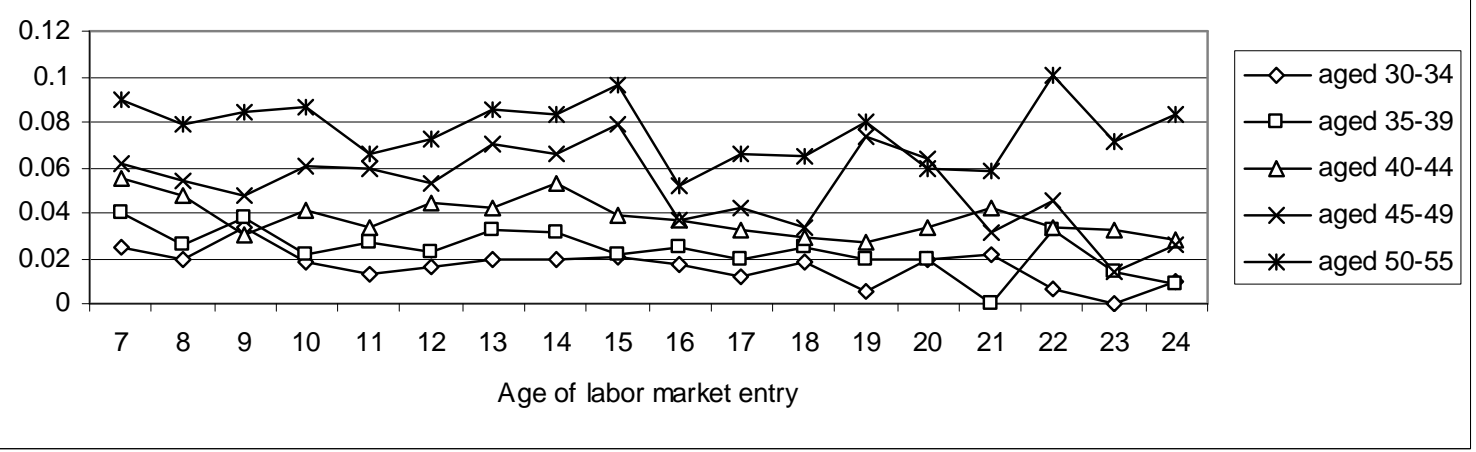


Appendix 1. (continued)

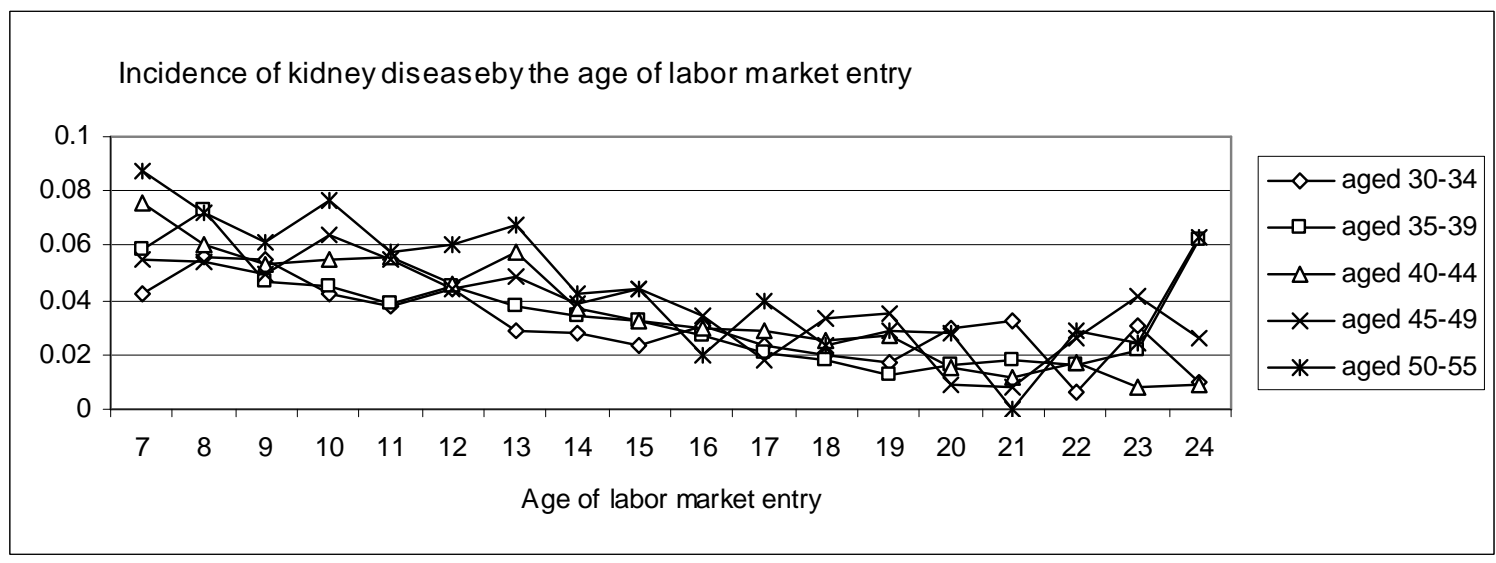

Incidence of depression by the age of labor market entry

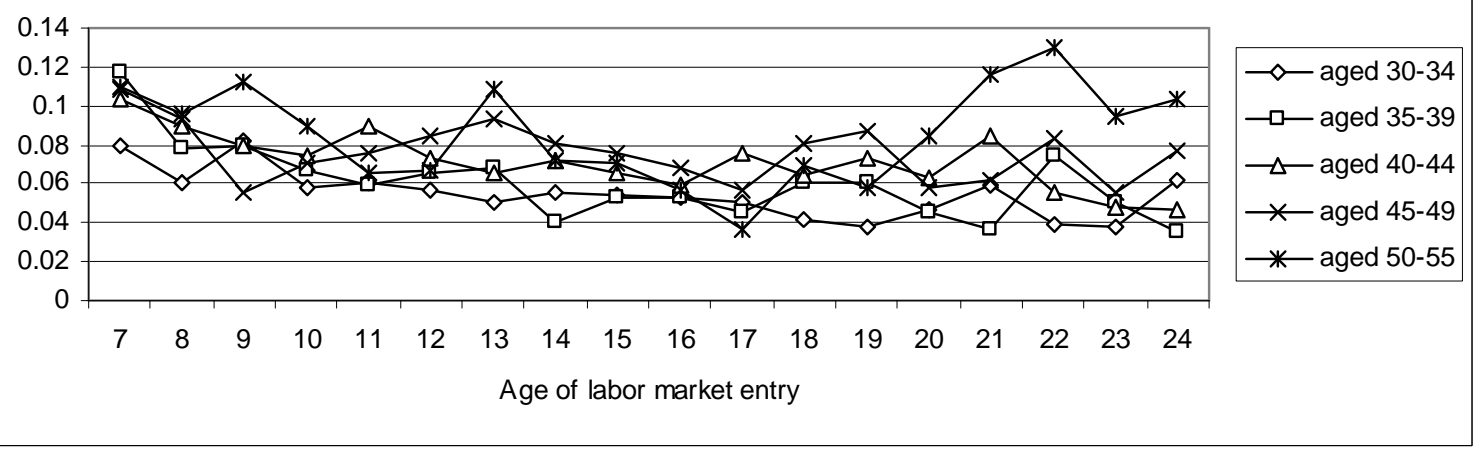

Incidence of tendonitis by the age of labor market entry

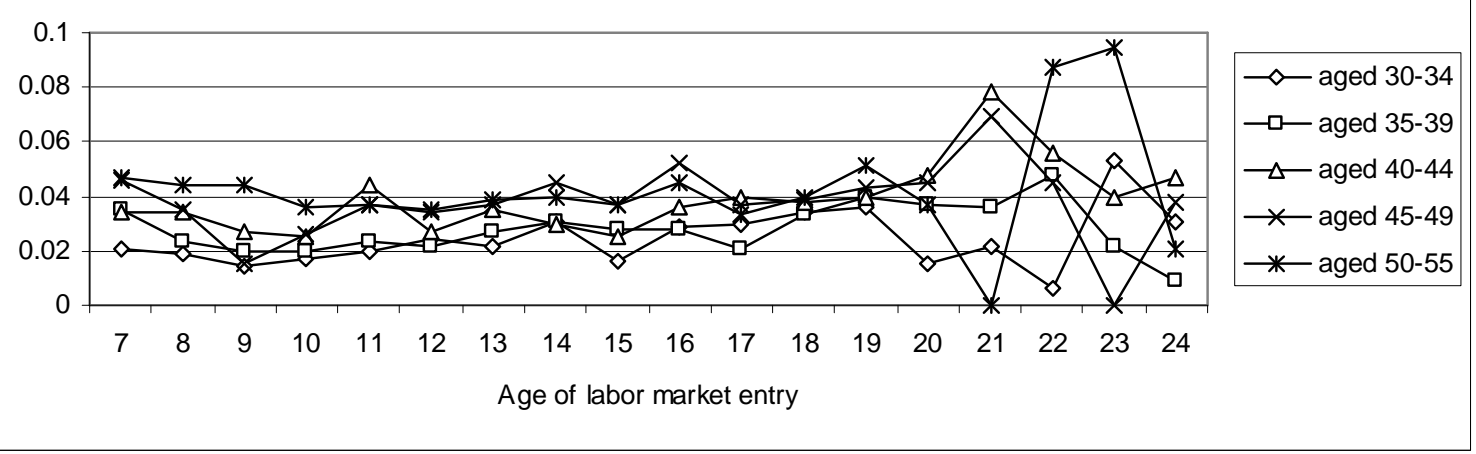

